\title{
CPFD simulation of petcoke and SRF co-firing in a full-scale cement calciner
}

Nakhaei, Mohammadhadi; Wu, Hao; Grévain, Damien; Jensen, Lars Skaarup; Glarborg, Peter; Dam-Johansen, Kim

Published in:

Fuel Processing Technology

Link to article, DOI:

10.1016/j.fuproc.2019.106153

Publication date:

2019

Document Version

Peer reviewed version

Link back to DTU Orbit

Citation (APA):

Nakhaei, M., Wu, H., Grévain, D., Jensen, L. S., Glarborg, P., \& Dam-Johansen, K. (2019). CPFD simulation of petcoke and SRF co-firing in a full-scale cement calciner. Fuel Processing Technology, 196, [106153]. https://doi.org/10.1016/j.fuproc.2019.106153

\section{General rights}

Copyright and moral rights for the publications made accessible in the public portal are retained by the authors and/or other copyright owners and it is a condition of accessing publications that users recognise and abide by the legal requirements associated with these rights.

- Users may download and print one copy of any publication from the public portal for the purpose of private study or research.

- You may not further distribute the material or use it for any profit-making activity or commercial gain

- You may freely distribute the URL identifying the publication in the public portal 


\title{
CPFD simulation of petcoke and SRF co-firing in a full-scale cement calciner
}

\author{
Mohammadhadi Nakhaei ${ }^{\mathrm{a}, \mathrm{c}, *}$, Hao $\mathrm{Wu}^{\mathrm{a}, *}$, Damien Grévain ${ }^{\mathrm{b}}$, Lars Skaarup Jensen ${ }^{\mathrm{b}}$, Peter \\ Glarborg $^{\mathrm{a}}$, Kim Dam-Johansen ${ }^{\mathrm{a}}$ \\ ${ }^{a}$ Technical University of Denmark, Department of Chemical and Biochemical Engineering, Lyngby \\ Campus, 2800 Kgs. Lyngby, Denmark \\ ${ }^{b}$ FLSmidth A/S, Cement RESD, Vigerslev Allé 77, 2500 Valby, Denmark \\ ${ }^{c}$ Sino-Danish Center for Education and Research, Beijing, China
}

\section{Abstract}

Computational particle fluid dynamics (CPFD) simulation is carried out to study the effect of petcoke and solid recovered fuel (SRF) co-firing in a full-scale cement calciner. The simulations are conducted using the Multi-Phase Particle-In-Cell (MP-PIC) approach with the Barracuda Virtual Reactor ${ }^{\circledR}$ 17.3.1 solver. The results from the CPFD simulation are compared with extensive field measurements of gas temperature and composition at several points in different calciner cross-sections. In the simulation, the SRF particles are divided into three components of plastic, biomass, and inert. The plastic particles go through drying, melting and decomposition while the conversion of biomass particles involves drying, devolatilization, and char oxidation. The predicted concentrations of $\mathrm{O}_{2}$ and $\mathrm{CO}_{2}$ are in good agreement with the measurements, while the gas temperature is overpredicted, especially in the lower calciner vessel. However, the trends of changes in the gas temperature are well-captured. The converted fuel fraction and calcination factor are predicted with an acceptable degree of accuracy. The simulation results show that large biomass particles in SRF tend to leave the calciner without complete conversion. Furthermore, a recirculation pattern for SRF particles is observed in the lower calciner vessel and the conical section, leading to high conversion degree of this fuel.

Keywords: cement calciner, gas-solid flow, computational particle fluid dynamics, solid recovered fuel, co-firing 
зо $\quad C_{p} \quad$ Specific heat capacity $[J / k g . K]$

${ }_{31} \quad C_{D} \quad$ Drag coefficient [-]

$32 \quad C_{S} \quad$ Smagorinsky coefficient [-]

${ }_{33} D_{p} \quad$ Drag function $[1 / s], \frac{3 \rho_{g} C_{D} U_{s l i p}}{4 \rho_{p} d_{p}}$

${ }_{34} \quad d_{p} \quad$ Particle diameter $[m]$

${ }_{35} \quad D_{t} \quad$ Turbulent diffusivity $\left[\mathrm{m}^{2} / \mathrm{s}\right]$

36 g Gravitational acceleration vector $\left[\mathrm{m} / \mathrm{s}^{2}\right]$

$37 \quad h \quad$ Enthalpy $[\mathrm{J} / \mathrm{kg}]$

38 $m$ Mass $[k g]$

39 $\quad M W$ Molecular weight $[\mathrm{kg} / \mathrm{mol}]$

${ }_{40} \quad \mathrm{~N} \quad$ Number of moles $[\mathrm{mol}]$

${ }_{41} \quad N u_{p} \quad$ Particle Nusselt number [-]

42 $P \quad$ Gas static pressure $[P a]$

${ }_{43} \quad \operatorname{Pr}_{g} \quad$ Gas Prandtl number [-]

${ }_{44} \mathrm{Pr}_{t} \quad$ Turbulent Prandtl number [-]

${ }_{45} \dot{Q} \quad$ Energy source term due to gas/particle reactions $\left[\mathrm{J} / \mathrm{m}^{3}\right]$

${ }_{46} \quad R \quad$ Universal gas constant $[J / m o l . K]$

${ }_{47} \quad R e_{p} \quad$ Particle Reynolds number [-], $\frac{\rho_{g} d_{p} U_{s l i p}}{\mu_{g}}$ 
${ }_{48} S c_{t} \quad$ Turbulent Schmidt number [-]

49 Sh Sherwood number [-]

${ }_{50} \quad T \quad$ Temperature $[K$ or $C]$

${ }_{51} \quad \mathbf{u} \quad$ Velocity vector $[\mathrm{m} / \mathrm{s}]$

${ }_{52} U_{\text {slip }} \quad$ Slip velocity $[m / s],\left|\mathbf{u}_{g \odot p}-\mathbf{u}_{p}\right|$

${ }_{53} \quad \mathbf{x}_{p} \quad$ Particle position vector $[m]$

${ }_{54} \quad Y_{g, i} \quad$ Mass fraction of $\mathrm{i}^{\text {th }}$ gas species [-]

55

${ }_{56}$ Greek symbols

${ }_{57} \Delta \quad$ LES filter width $[m]$

${ }_{58} \quad \epsilon_{p} \quad$ Particle emissivity [-]

${ }_{59} \theta \quad$ Volume fraction [-]

${ }_{60} \quad \theta_{C P} \quad$ Close-pack particle volume fraction [-]

${ }_{61} \quad \kappa_{g} \quad$ Gas thermal conductivity $[W / m . K]$

${ }_{62} \kappa_{t} \quad$ Turbulent thermal conductivity $[W / m . K]$

${ }_{63} \mu_{g} \quad$ Gas molecular viscosity, [Pa.s]

${ }_{64} \quad \mu_{t} \quad$ Turbulent viscosity, $[$ Pa.s $]$

${ }_{65} \rho \quad$ Density $\left[\mathrm{kg} / \mathrm{m}^{3}\right]$

${ }_{66} \quad \sigma \quad$ Stefan-Boltzmann coefficient $\left[W / m^{2} \cdot K^{4}\right]$

${ }_{67} \tau_{N S} \quad$ Particle normal stress $[P a]$ 
${ }_{68} \tau_{p} \quad$ Particle inertial response time $[s], \frac{\rho_{p} d_{p}^{2}}{18 \mu_{g}}$

${ }_{69} \quad \tau_{T} \quad$ Particle thermal response time $[s], \frac{C_{p_{p} \rho_{p} d_{p}^{2}}}{12 \kappa_{g}}$

${ }_{70} \phi \quad$ Wadell's degree of sphericity [-]

71

72 Subscripts

$73 \quad g \quad$ Gas phase parameter

${ }_{74} i \quad$ Belonging to $i^{\text {th }}$ gas species phase

${ }_{75} \quad p \quad$ Particle phase parameter

${ }_{76} \quad r \quad$ Reaction

77

78 Symbols

79\langle\rangle$\quad$ Time-averaged value

80 $[i] \quad$ Concentration of gas species i $\left[\right.$ mol.m $\left.\mathrm{m}^{-3}\right]$

${ }_{81} \odot p \quad$ Interpolated value from the Eulerian grid to the particle position

\section{Introduction}

Cement production contributes to around $18 \%$ and $5 \%$ of $\mathrm{CO}_{2}$ emission in the industry sector and the globe, respectively [1]. In the past two decades, there has been an increased interest in the cement industry toward substitution of fossil fuels with waste derived fuels, especially in cement calciners where around $35-60 \%$ of the total fuel of the factory is fired [2]. This fuel replacement is driven by both economical and environmental motivations. Compared to fossil fuels, firing waste derived fuels in the cement calciner is usually cheaper 
or even free. Besides, the biomass part of waste derived fuels is considered as a $\mathrm{CO}_{2}-$ neutral fraction [3], reducing the net $\mathrm{CO}_{2}$ emissions from cement production process. Furthermore, firing waste derived fuels in the cement calciner is considered as a proper alternative for environmentally unfriendly waste disposal methods such as landfilling. Cement calciners operate at high temperature conditions, typically around $850-1150^{\circ} \mathrm{C}$, suitable for combustion of these fuels. Moreover, the ash of the fuel will be incorporated in the clinker product [4, removing the need for solid residue disposal that exists in waste incineration plants.

Refuse derived fuel (RDF) is typically referred to the combustible fraction of municipal solid waste (MSW) and/or industrial waste produced using different waste treatment techniques [5]. In general, RDF can be considered as any type of waste-derived fuel that is going to be used for energy production [6]. Solid recovered fuel (SRF) is a certified type of RDF that its quality is evaluated based on a series of standards, i.e., CEN/TS 343 [7], and categorized into five classes based on calorific value and chlorine and mercury contents [7]. SRFs differ significantly from the conventional pulverised solid fuels (e.g., coal and petcoke), both in physical and combustion properties. As a result, replacement or co-firing of conventional pulverised solid fuels with SRFs may change the operating conditions of cement calciners. Even though this replacement is investigated widely for other types of industrial furnaces (e.g., rotary kilns [4, 8-10], utility boilers [11 15], etc.), reported studies in the area of cement calciners are limited.

One of the main challenges in firing SRF in cement calciners is incomplete burnout of fuel particles when they leave the calciner together with the calcined meal particles to the lowest cyclone stage. This phenomenon can lead to reduced cement quality [4, 16] and increased probability of melt-induced build-ups formation in the rotary kiln and the preheater system [17]. The burnout problem mainly stems from the larger size (typically in the millimeter- and centimeter-range) and higher moisture content (typically in the range of 5-30 wt.\%) of SRF particles compared to the conventional solid fuel particles. The slow conversion rate of large fuel particles is due to the limitations in external and 
internal heat transfer and oxygen diffusion rates [18, 19]. Accordingly, in order to suppress the particle burnout problem, it is common to specify a limit for the size of SRF particles fired in the calciner (e.g., $90^{\text {th }}$ percentile grain size smaller than $80 \mathrm{~mm}$ [20]). Besides the conversion degree, addition of waste derived fuels to the calciner alters the operating conditions and, in turn, changes the emission levels (e.g., $\mathrm{NO}_{\mathrm{x}}$ and $\mathrm{CO}$ ) of the calciner. For example, Mikulčić et al. 21] investigated co-firing of coal and SRF in a separate line calciner using computational fluid dynamics (CFD) simulations; and reported reduced temperature peaks in the oxidation region of the calciner when SRF particles were fired along with the pulverized coal particles. This is due to the delay in devolatilization of SRF particles as the fuel moisture evaporation is extended [21].

A direct method to study the impact of SRF co-firing on the performance of calciner systems is through on-site measurements. However, full-scale measurements in calciner are very costly and also complicated due to the intense operating conditions inside the reactor (i.e., dusty environment). Furthermore, some co-firing practices require a modification of the cement calciner itself (e.g., addition of a feeding system for firing the new fuel) which makes a posteriori experiments impractical.

An alternative practice to assess the effect of co-firing in the calciner systems is conducting CFD simulations. The two main CFD approaches for gas-solid reactive systems are the Eulerian-Eulerian (EE) and Eulerian-Lagrangian (EL) methods. In the EE method, the solid phase is considered as a continuum medium and additional closure terms are required to model the particle-particle interactions. The EE approach is usually utilized for mono-dispersed gas-solid systems and in the case of poly-dispersed particles, extra momentum and continuity equations should be solved for each size bin with the cost of more computational overhead [22, 23]. In the EL approach, solid particles are tracked in a Lagrangian frame and the solution can be readily applied for the poly-dispersed particles. One of the challenges of this method is resolving particle-particle interactions that can be computationally expensive for industrial-scale and/or dense gas-solid systems. As a solution, hybrid EE-EL approaches, such as the Multi-Phase Particle-In-Cell (MP- 
PIC) method, can be utilized. In the MP-PIC method, the particle-particle interactions are modelled by employing a particle stress term in Lagrangian equations of the particle motion [24, 25]. This method has been successfully applied in simulation of reactive gassolid systems [26-29]. In the case of reactive calciner systems, the EL method [30-37] is utilized more frequently than the EE method [38], while to the authors' knowledge, the application of the MP-PIC method has not been explored yet.

The existing CFD simulation studies of calciner systems are mostly focused on either the aerodynamics of the gas-solid flow (without reactions) [33, 39 45] or the combustion of conventional fossil fuels in the calciner [30,32, 34, 37, 46, 51]. There are only a limited number of literature studies that investigate calciners operating with alternative fuels including car tyre chips [52], co-firing of coal and biomass [53], and co-firing of fossil fuels and SRF 21, 54. In most of the mentioned studies, either no validation (of any kind) of the CFD model is provided [33, 39, 40, 44, 45, 49] or the sub-models used in the CFD study are separately validated without any direct comparison of the CFD predictions results with the full-scale measurements [21, 34, 36, 50, 53]. For studies that have compared the CFD simulation results with the full-scale measurements, the comparison is usually qualitative [30, 43], or only at the calciner exit [31, 32, 37, 41, 48, 51]. Only in few studies of reactive calciners, the comparison of CFD predictions with the fullscale measurements is carried out at a number of points along the calciner height, i.e., a total number of 6 point measurements of gas temperature and velocity at 2 different calciner cross-sections [46, gas temperature and velocity measurements at around 5 calciner cross-sections [47, and gas temperature and $\mathrm{NO}_{\mathrm{x}}$ measurements at around 5 calciner cross-sections [54].

Based on the literature survey above, it can be stated that CFD simulation of SRF co-firing in a cement calciner supported by extensive comparison with full-scale measurements has not been reported in open literature. In the present study, the performance of a full-scale calciner operating with SRF and petcoke is evaluated experimentally through extensive measurements of gas temperature and gas species concentration at different 
locations of the calciner. Furthermore, a computational particle fluid dynamic (CPFD) model is adopted to simulate the calciner. In the CPFD model, solid particles are tracked in a Lagrangian frame using the MP-PIC approach. The sub-models used for conversion of different SRF particle types are previously developed and validated [55, 56]. Finally, predictions from the CFD simulations and the measurements are compared throughout the calciner, and suggestions for improving the accuracy of the simulation are provided.

\section{Experimental}

In the present study, full-scale measurements are carried out for an in-line calciner (ILC) system operating with a mixture of SRF and petcoke. A schematic representation of the studied ILC system is presented in Fig. 1. The calciner is approximately $80 \mathrm{~m}$

high and comprised of a riser section, two main vessels divided by a constriction, and a swanneck. During the measurement period, it has been attempted to maintain a stable operating condition of the cement plant. On average, the clinker production rate is 3488 tonnes per day, and the thermal shares of fuel fired in the calciner and the rotary kiln are 61 and 39\%, respectively. In the calciner, both petcoke and SRF are fired with approximate mass flow rates of 0.4 and $5.1 \mathrm{~kg} / \mathrm{s}$, respectively. Samples of petcoke and SRF fired in the calciner are taken from the cement plant during the measurements and the proximate and ultimate analysis of these fuels are provided in Table1. The preheater system is composed of 5 stages of cyclones, and $45 \%$ of the raw meal materials from the $3^{\text {rd }}$ cyclone stage are split and fed to the upper calciner vessel. The amount of split is regulated to maintain the temperature at the constriction to around $1000^{\circ} \mathrm{C}$. The rest of the raw meal is supplied from the $4^{\text {th }}$ cyclone stage to the lower calciner vessel, while the raw meal feed pipe to the riser section was blocked during the measurements. As a result of fractionating the raw meal between the upper and lower calciner vessels, the endothermic calcination reaction takes place less strongly in the lower calciner vessel, leading to an increased gas temperature in this vessel. The gas temperature in the lower calciner vessel can influence the calciner performance, such as fuel burnout degree, $\mathrm{NO}_{\mathrm{x}}$ 
emission, etc.

The reported parameters in this study correspond to the time-averaged values during the stable period of operation. The gas temperature and species concentrations are measured at different locations throughout the calciner. The cross-sections at which the measurements are carried out are also presented in Fig. 1. In each measurement cross-section, the measurements are conducted at several points with the number of point-measurements depending on the number of accessible holes on the calciner walls.

\subsection{Temperature measurements}

The temperature measurements are conducted using sets of $3 \mathrm{~K}$-type thermocouples carried by bundles of steel tubes. Each tube bundle is composed of 3 steel tubes of 4, 3, and $2 \mathrm{~m}$, long. The arrangement is in a way that the tip of each thermocouple is placed outside of the corresponding steel tube and distanced $1 \mathrm{~m}$ from the neighbouring thermocouple(s). For most of the cross-sections, all three thermocouples are used, with the tips of thermocouples distanced 1,2 , and $3 \mathrm{~m}$ from the internal calciner refractory wall. If the cross-sectional area of the measurement plane is limited, only two thermocouples of the tube bundle are used for the measurements. The temperature measurements are carried out for a minimum time span of 15 minutes, while for some of the measurements, this period was extended to more than 1 hour.

The used thermocouples belong to the tolerance class 1 , i.e. $\pm 2.5^{\circ} \mathrm{C}$. Thermocouples had either Inconel-600 protective sheath (used in the riser section and reduction zone) or AISI-314 (used in calciner vessels and swanneck) with maximum measurable temperatures of 1350 and $1100^{\circ} \mathrm{C}$, respectively. The main uncertainty in the gas temperature measurements stems from the radiative heat transfer between the thermocouple and the surroundings (e.g., calciner refractory wall and fuel or raw meal particles). An estimation of this uncertainty is presented in the supplementary material (section 1). According to this estimation, it can be stated that for gas and environment temperatures of $1000^{\circ} \mathrm{C}$ $900^{\circ} \mathrm{C}$, the measured temperature can be lower than the actual gas temperature by 56 and $47^{\circ} \mathrm{C}$ for the superficial gas velocities of 35 and $5 \mathrm{~m} / \mathrm{s}$, respectively. In the present study, 
no correction for this uncertainty is provided due to lack of a quantitative measurement for the environment temperature at the measurement cross-sections.

\subsection{Gas species measurements}

The gas species concentration is measured using a system of a water-cooled probe, a filter, a gas conditioning unit, and a gas analyser connected by polyethylene tubes. Two water-cooled probes with different lengths are used, both made of three concentric stainless steel tubes. The inner tube, with approximate outer diameter of $10 \mathrm{~mm}$, is used for gas extraction while the rest of the tubes are used for water flows. For each point measurement, it is aimed to extract the gas for a period of 8 minutes providing a useful signal period of 5-6 minutes. For some measurements, this measurement period is shortened due to blockage of the inner gas tube with the materials from the calciner, e.g., dust, char, etc. Compressed air is used for cleaning or reopening the inner gas tube after each measurement. Apart from the mentioned probes, KilnLoq ${ }^{\mathrm{TM}}$ water-cooled probe [57] is used for gas extraction at point 6-1 cross-section (see Fig. 1) during the whole measurement campaign. The gas extraction section of this probe is cleaned automatically using pressurized air with a time interval of 10-15 minutes.

The gas extracted by KilnLoq ${ }^{\mathrm{TM}}$ probe is analysed by URAS-10 gas analyser, measuring $\mathrm{NO}, \mathrm{CO}, \mathrm{O}_{2}$, and $\mathrm{SO}_{2}$ gas concentrations in dry conditions. The normal water-cooled probes are connected to URAS-14 gas analyser, providing measurements of $\mathrm{NO}, \mathrm{CO}, \mathrm{O}_{2}$, and $\mathrm{CO}_{2}$ gas concentrations in dry conditions. The gas analysers were calibrated prior to the measurements. In the present study, only $\mathrm{O}_{2}$ and $\mathrm{CO}_{2}$ concentrations are reported.

\section{Numerical model description}

In this study, the CPFD simulations are conducted using Barracuda Virtual Reactor ${ }^{\circledR}$ 17.3.1 solver. This solver has been successfully applied for CFD simulation of reactive/nonreactive dense/dilute transport of gas-solid flows, e.g., circulating fluidized beds [27, 58], fluid catalytic cracking risers [59], a cold pilot calciner [60], etc. In this section, a summary of the modelling details is presented. 


\subsection{Governing equations of the fluid and particles}

The gas-solid flow in the calciner is solved using an Eulerian-Lagrangian approach for the carrier fluid and the suspended particles (i.e., raw meal and fuel particles), respectively. In the Lagrangian tracking of particles, the Multi-Phase Particle-In-Cell (MP-PIC) algorithm [26] is used. This approach has been widely utilized for CFD simulation of dense and dilute gas-solid systems (for example, see [28, 61, 62]). Large eddy simulation is applied to resolve energy containing structures of the flow while the unresolved structures are modelled using the classical Smagorinsky model [63]. The Eulerian equations of mass, momentum, energy, and gas species transport as well as the Lagrangian equations of solid particles are summarized in Table 2 .

In the presented table, the LES filtering symbol is not shown for simplicity and the vector or tensor variables are shown as bold characters. $g$ and $p$ subscripts indicate the gas and solid phases, respectively. The term $\delta \dot{m}_{p}$ is the production rate of gas mass per unit volume due to heterogeneous reactions, and $\dot{m}_{i, c h e m}$ is the gas species source term due to homogeneous and heterogeneous reactions. $\dot{Q}_{g}$ is the source term of gas energy per unit volume. It is assumed that the turbulent Prandtl and Schmidt numbers, $P r_{t}$ and $S c_{t}$, are constant all over the domain and equal to 0.9 [26]. As the gas flow is compressible, the partial pressure of the gas species $i$ with molecular weight of $M W_{i}$ can be related to the gas density through the equation of state for ideal gasses as below,

$$
P_{i}=\frac{\rho_{g} Y_{g, i} R T_{g}}{M W_{i}}
$$

and the gas pressure, $P$, is the sum of partial pressures of all gas species. The molecular viscosity, $\mu_{g}$, molecular thermal conductivity, $\kappa_{g}$, gas specific heat, $C p_{g}$, and gas enthalpy $h_{g}$ are calculated according to a mass-based weighting of different gas species. In the solution provided by the solver, the gas temperature is approximated from the gas species mass fractions and enthalpies using a piecewise linear approximation [26]. 
For grid cell $\zeta$ with the volume of $V_{\zeta}$ and containing $N_{p}$ computational particles, the gas-solid coupling terms in continuity, momentum, and energy equations can be written as follows [26],

$$
\begin{aligned}
& \delta \dot{m}_{p}=\frac{1}{V_{\zeta}} \sum_{1}^{N_{p}} S_{\zeta, p} n_{p} \frac{d m_{p}}{d t} \\
& \mathbf{F}_{\mathbf{p}_{\zeta}}=\frac{1}{V_{\zeta}} \sum_{1}^{N_{p}} S_{\zeta, p}\left\{m_{p}\left[D_{p}\left(\mathbf{u}_{g \odot p}-\mathbf{u}_{p}\right)-\frac{\nabla P_{g \odot p}}{\rho_{p}}\right]+\mathbf{u}_{p} \frac{d m_{p}}{d t}\right\} n_{p} \\
& \mathbf{F}_{\mathbf{T}_{p_{\zeta}}}=\frac{1}{V_{\zeta}} \sum_{1}^{N_{p}} S_{\zeta, p}\left(m_{p} C_{p_{p}} \frac{d T_{p}}{d t}+h_{p} \frac{d m_{p}}{d t}\right) n_{p}
\end{aligned}
$$

where $n_{p}$ and $m_{p}$ are the number of real particles in each particle cloud and the mass of each particle, respectively, and $S_{\zeta, p}$ is the operator for interpolating the particle variables into the Eulerian grid.

\subsection{Particle drag models}

In the present study, SRF fuel particles are classified into three groups of plastic, biomass, and inert particles. Wind sieve experiments are carried out for the SRF sample taken during the measurements, dividing these three groups into 5 subgroups each. The particles of each subgroup have a specific terminal velocity in the ranges of $<2,2-3$, $3-5,5-7$, and $>7 \mathrm{~m} / \mathrm{s}$. For each subgroup, the distribution of particle size and shape is selected based on the previously measured values reported in [55], and summarized in the supplementary material (section 2).

For petcoke fuel particles, the homogeneous Wen-Yu drag model [64, 65] is used. For the biomass fraction of SRF particles, according to the physical and aerodynamic study of individual SRF particles in [55], the non-spherical Ganser drag model [66] with a constant 
multiplier is employed. For the plastic particles in SRF, it is assumed that the shape of particles changes to a near-spherical shape after the melting process. Hence, the particle shape is considered constant and close to spherical during the whole conversion process. The Ganser drag model [66] is used for aerodynamic modeling of plastic particles.

The drag model used for the raw meal particles is a combination of the Wen-Yu drag model and EMMS multipliers [67, 68]. Two sets of EMMS/matrix multipliers are generated for the raw meal particles fed to the lower and upper calciner vessels. The parameters that are used for generating the EMMS/matrix multipliers are summarized in section 2 of the supplementary material. The EMMS drag model is successfully applied in the previous CPFD study by the authors for the gas-solid flow in a cold pilot-scale calciner [60]. It is worthy to mention that the parameters that are important in generation of the EMMS/matrix multipliers (e.g., solid mass flux, particle size, superficial gas velocity, etc.) change as a function of calciner height due to the homogeneous and heterogeneous reactions. However, it is reported that even if the EMMS/matrix is made based on operating conditions different from the actual system operating conditions, still reasonable predictions can be obtained [69].

\subsection{Chemical Reactions}

The gas phase homogeneous reactions considered in this study are oxidation of methane as the two-step global reaction proposed by Westbrook and Drier [70], with rate constants according to [71]. The heterogeneous reactions of raw meal as well as solid fuel particles are described briefly here and summarized in section 3 of the supplementary materials.

\subsubsection{Reactions associated with raw meal particles}

The most important reaction that the raw meal particles go through in a calciner is calcination. In this study, the calcination reaction rate is considered to be a function temperature while being inhibited by the presence of $\mathrm{CO}_{2}$ in the gas phase. The forward reaction rate coefficient is derived by fitting the model to the experimental data of [72, 73] while the reverse reaction is determined from the forward rate and the knowledge of $\mathrm{CO}_{2}$ 
equilibrium pressure. The reaction temperature is weighted with the gas and particle temperatures with factors of 0.9 and 0.1 , respectively, because the original experimental data are based on the operating gas temperature of the corresponding reactor. It is assumed that the raw meal particles are composed of $\mathrm{CaO}, \mathrm{CaCO}_{3}$, and an inert compound and the particle shrinks as the calcination reaction proceeds. The effect of belite formation is taken into account by reducing the enthalpy of the calcination reaction.

\subsubsection{Conversion of petcoke particles}

The petcoke particles are assumed to be composed of ash (inert content), fixed carbon and volatiles. Solid petcoke particles go through devolatilization and char oxidation reactions during the conversion process. As the moisture content in petcoke is not significant, the evaporation process is incorporated in the devolatilization. The devolatilization process takes place as a single step first order reaction and the products are considered to be $\mathrm{H}_{2} \mathrm{O}, \mathrm{CH}_{4}$, and $\mathrm{CO}$. The devolatilization reaction temperature, $T_{r}$, is weighted by 0.2 and 0.8 with the gas and particle temperatures, respectively, which are the default (and non-changeable) values in the software.

In the existing studies of petcoke char oxidation, three reaction zones are identified depending on the oxidation temperature [74, 75]. In the present study, the reaction rates of Young and Smith [74], which are derived for the temperature range of 1000$1800 \mathrm{~K}$, are used. In this temperature range, char oxidation lies in "Zone II" where the internal pore diffusion is rate limiting. The overall reaction rate for petcoke char oxidation [75, 76] is considered as a combination of inherent chemical reaction rate [74] and external oxygen diffusion rate [77]. It is assumed that CO is the only product of char oxidation. It is possible that the particles would have a higher temperature than the gas due to the exothermic char oxidation reaction. Accordingly, the reaction temperature, $T_{r}$, is weighted by 0.1 and 0.9 with the gas and particle temperatures, respectively. The gas weighting factor of 0.1 is considered to improve stability of the solution. 


\subsubsection{Conversion of SRF plastic particles}

It is assumed that the plastic particles constitute moisture, volatile, and ash contents. The plastic particles in SRF are assumed to go through moisture evaporation [78], melting and decomposition processes [56]. The particles are considered as isothermal with constant sphericity and emissivity throughout the conversion process. It is reported that in calciner operating conditions and for plastic particles lighter than $1000 \mathrm{mg}$, the total conversion time predicted using an isothermal model is within $\pm 30 \%$ of the value predicted by a detailed non-isothermal model [56].

The original heats of melting and decomposition for plastic particles are 207 and 365 $k J / k g$, respectively [56, 79]. In the present study, for plastic conversion, it is assumed that: $\mathrm{CH}_{4}$ is the only product of decomposition, the specific heat capacities of solid and liquid phases change with temperature and are equal to the gaseous $\mathrm{CH}_{4}$ specific heat capacity, and the heats of melting and decomposition are modified in a way that the total thermal energy required for complete particle heating, melting, and decomposition would be the same compared to a plastic particle with original heats of melting and decomposition and specific heat capacity. Furthermore, the mass flow rate of SRF plastic fraction is modified to conserve the energy input to the system from oxidation of $\mathrm{CH}_{4}$ released from plastic decomposition. Using this method, the decomposition heat for plastics is fixed to a constant value independent of the decomposition temperature.

\subsubsection{Conversion of SRF biomass particles}

The conversion of biomass particles in suspension condition is widely studied in the literature (e.g., see [80 82]). Various complexities may arise for modelling the conversion of large biomass particles in gas-solid systems, e.g., combined effects of particle shrinkage and intra-particle heat transfer [83] and a possible change in the Geldart classification during the conversion of biomass particles [84] in fluidized beds. Furthermore, even though this subject is widely investigated in the literature, in most of the studies, the focus is limited to a specific type of biomass such as wood [18, 85]. In the current study, 
the biomass particles are assumed to be composed of ash, fixed carbon, volatile, and moisture contents. Similar to the plastic particles, the biomass particles in SRF are modelled as isothermal particles of constant sphericity and emissivity. The conversion model is comprised of moisture evaporation [78] and devolatilization [18] at fixed particle size, and char oxidation [8, 86, 87], considering a shrinking particle model.

It is considered that biomass volatiles are composed of a mixture of $\mathrm{CH}_{4}$ and $\mathrm{CO}$. The reaction rates of devolatilization and char oxidation [8] are chosen according to predicted total devolatilization and char oxidation times and comparison with the existing literature data of different types of biomass [4, 88, 90] in a wide range of oxygen concentrations and gas temperatures. Using the presented model, the maximum average deviation of the predicted devolatilization and char oxidation times compared to the existing experimental data, is below $15 \%$ and $20 \%$, respectively [8]. The biomass moisture evaporation reaction rates are similar to the ones for plastic fraction.

The inert particles are comprised of only moisture and ash contents and they only go through moisture evaporation.

The assumed volatiles composition considered in this study, to conserve the energy input to the system from fuels conversion, can change the amount of $\mathrm{O}_{2}$ required for complete combustion of the whole fuel. The air-fuel equivalence ratio of the whole calciner, $\lambda$, changes from 1.36 to 1.32 after implementing this assumption. Subsequently, as $\lambda$ is reduced slightly, the conversion rates that depend on the oxygen concentration in the gas (e.g., petcoke and biomass char oxidation) may be attenuated to some extent.

\section{Operating and boundary conditions}

An overview of the studied calciner along with the location of boundary conditions is presented in Fig. 2 and a detailed description of each boundary condition is provided in Table 3. To have a better characterization of the gas flow in the riser section, besides the calciner itself, a part of the rotary kiln with removed volume of the raw meal filling is considered as the simulation domain. 
At the raw meal particle inlets in the lower and upper calciner vessels, special spreader plates with curved surfaces are placed with a downward angle in order to properly distribute the flow of raw meal particles in the calciner cross-section. The raw meal particles are fed to the calciner with a velocity in the range of $5-10 \mathrm{~m} / \mathrm{s}$. The distribution of the amount of raw meal fed to the lower and upper calciner vessels (or the amount of split from stage 3 cyclone to the upper calciner vessel) is determined based on an energy balance of the preheater system and corresponding temperatures in the cyclones and the calciner. The accuracy of this method depends on the uncertainties from temperature sensors placed in the cyclones and the calciner.

The petcoke fuel particles along with their corresponding transport air are fed to the riser section of the calciner The gas and particle velocities are calculated based on the volumetric gas flow in the fuel transport pipes. The three fractions of SRF (i.e., biomass, plastic, and inert) are fed only from one location, slightly downstream of the petcoke injection.

The main gas inlets of the calciner are the flue gas from the rotary kiln and the tertiary air. Both of these streams are laden with dust particles. The dust particles are assumed to be fully calcined, composed of only $\mathrm{CaO}$, and have the same velocity as that of the carrier gas when they enter the computational domain. Some of the gas and laden dust particles (around 7\%) entering the simulation domain from the kiln inlet leave from a bypass placed upstream of the riser section. The main outlet of the domain is placed at the exit of the swanneck.

To reduce the complexity of the problem, calciner walls are considered as adiabatic. Instead, the enthalpy of the calcination reaction is added by around $41 \mathrm{~kJ} / \mathrm{kg}$ of $\mathrm{CaCO}_{3}$ to account for the expected heat transfer loss from the walls. This distributes the wall heat transfer loss over the extent of calcination which may cause some uncertainty in the predicted gas temperature profiles. A no-slip gas velocity boundary condition is assumed at the walls and the $k-\epsilon$ wall function is considered for the computational cells close to the wall [25, 91]. It should be noted that the contribution of any possible buildups 
on the internal geometry of the calciner is not taken into account. The formation and destruction of buildups on the calciner walls can happen dynamically and as a result, the internal geometry may be slightly different from the assumed geometry.

\section{Computational details}

In the finite volume solver of the software, the advection terms in mass, momentum, energy, and gas species transport equations are estimated at the cell faces using the partial donor cell approach; which is a weighted average between central differencing and upwind convection schemes [91]. Other fluid parameters such as pressure and temperature are calculated at the cell centres.

A Cartesian cut cell grid is generated using the build-in module available in Barracuda Virtual reactor ${ }^{\circledR}$ version 17.3.1. In the riser section and lower calciner vessel, the numerical cells have almost the same aspect ratios in all directions. For the upper calciner vessel and the swanneck, the cell size in the stream-wise direction increases with a linear growth factor. In total, the grid contains around 753,000 computational elements. The simulations are carried out for a period of 90 seconds with the time-averaging procedure starting after the solution has already reached a steady state condition, i.e., at 45 seconds. The steady state condition is checked through tracking different parameters in time such as the total number of computational particles in the domain and the mass flow rates of different particle and gas species exiting the calciner.

\section{Results and discussions}

\subsection{Comparison between the CPFD predictions and the measurements}

In the below two sections, overall and cross-sectional comparisons between the measured and predicted gas temperature and species concentrations along the calciner are presented. 


\subsubsection{Overall comparison}

Presented in Fig. 3 are comparisons of mass flow-averaged and area-averaged gas $\mathrm{O}_{2}$ and $\mathrm{CO}_{2}$ concentrations predicted from CPFD simulation with the measured values along the calciner. In this plot, the symbols are arithmetic average of different point measurements in each cross-section while the error bars correspond to the maximum and minimum (time-averaged) measured values. The area-averaged and mass flowaveraged values are integrated over the whole cross-section at each height, and deviate from each other, mainly because of non-uniformity of stream-wise gas velocity in the cross-section. According to the authors' opinion, it is more reasonable to compare the measurement data with the area-averaged values from the CPFD simulations because the point measurements are conducted without any knowledge of local mass flow rate of the gas over each cross-section. However, to provide a more accurate picture of the process along the reactor, the mass flow-averaged values are also reported which are more meaningful from mass and energy balance points of view. In summary, gas $\mathrm{O}_{2}$ and $\mathrm{CO}_{2}$ concentrations are predicted with an acceptable degree of accuracy.

According to Fig. 3, the $\mathrm{O}_{2}$ concentration decreases abruptly from the riser to the reduction zone due to fast oxidation of volatiles released from the fuel while at the end of the reduction zone, the $\mathrm{O}_{2}$ concentration increases again when the tertiary air is added to the main flow. $\mathrm{CO}_{2}$ increases abruptly from the riser to the reduction zone due to the calcination and fuel oxidation reactions while at the end of the reduction zone, it decreases because of addition of the tertiary air.

Downstream of the reduction zone, the fuel oxidation and calcination reactions mainly take place in the lower and upper calciner vessels. In the swanneck, the $\mathrm{O}_{2}$ concentration is slightly overpredicted while no information regarding $\mathrm{CO}_{2}$ at this point is available from the measurements. More discussion regarding the progress of different reactions throughout the calciner is provided in section 6.2 .

Comparison of the predicted and measured gas temperature along the calciner is presented in Fig. 4. The gas temperature increases rapidly in the reduction zone and 
afterwards, decreases in the lower and upper calciner vessels mainly because of exothermic fuel oxidation and endothermic calcination reactions, respectively. The gas temperature is overpredicted by around $100-150^{\circ} \mathrm{C}$ in the lower and upper calciner vessels. The amount of overprediction is, however, reduced to below $50^{\circ} \mathrm{C}$ in the swanneck. The overall trends of the measured gas temperature are well-captured by the CPFD simulations.

It will be shown in subsequent sections that the calcination of the raw material fed to the lower calciner vessel is predicted to be almost completed at the constriction, while according to Fig. 4, the temperature is overpredicted especially in the lower calciner vessel. This can be attributed to the assumption that belite formation proceeds along with the calcination reaction, while in reality, it takes place after $\mathrm{CaO}$ is produced from calcination. As a result, the gas temperature may be overpredicted to some extent in the lower parts of the calciner where the belite formation is less strong. Other possible reasons for the gas temperature discrepancy are: the uncertainly in the gas temperature measurement method described in section 1 of the supplementary material, considering a simplified gas phase chemistry for oxidation of volatiles, and uncertainty in the amount of hot meal split from the third stage cyclone to the calciner.

\subsubsection{Detailed cross-sectional comparison}

Cross-sectional distribution of gas temperature and $\mathrm{O}_{2}$ and $\mathrm{CO}_{2}$ species concentrations predicted from CPFD simulation are presented in Figs. 5, 6, and 7 and compared with the data from full-scale measurements. In these figures, the comparison is provided at point measurements as well as cross-sectional area-averaged values.

In the riser cross-section (i.e., point 1-2), the predicted distributions of gas temperature and species concentration are uniform. This indicates that no reaction takes place upstream of the riser section and the predicted parameters are equal to the values set as the kiln inlet boundary condition. However, the cross-sectional distributions of measured gas temperature and species concentration are slightly non-uniform which is due to the false air entering the calciner from the kiln seal (i.e., connection between the rotary kiln and the calciner). 
In the reduction zone (i.e., point $2-1$ ), high $\mathrm{CO}_{2}$ and low $\mathrm{O}_{2}$ concentrations are predicted in the east side of the cross-section most likely due to recirculation of solid species in this region. Furthermore, the gas temperature in this region is somewhat lower especially near the wall indicating higher contribution of calcination reaction from recirculation of solids. High $\mathrm{O}_{2}$ concentration spot in the southwest region of the cross-section corresponds to the trace of transport air carrying RDF particles to the calciner. Comparing the CPFD simulation results with the measurements, it can be stated that for most of the point measurements, the predicted values are different from the measured ones. However, as the measurements are limited to the points close to the calciner walls and not in the central regions, the actual distributions cannot be completely identified over the whole cross-section.

In the lower calciner vessel (i.e., point 3-1), the predicted gas temperature is higher than the measured value; but the uniformities of the measured and predicted gas temperature over the cross-section are qualitatively similar. At the points where the measurements are carried out, the measured and predicted gas temperatures are in the range of $909-986^{\circ} \mathrm{C}$ and $1059-1103^{\circ} \mathrm{C}$, respectively. From the predicted gas species concentrations, the tertiary air gas stream (fed to the calciner approximately $9 \mathrm{~m}$ upstream of the cross-section and from the southeast side) can be traced in the west side of the cross-section which is in agreement with the measurements. In total, the non-uniformity of the gas species concentrations from the simulation is overpredicted compared to the measurements. The measured $\mathrm{O}_{2}$ and $\mathrm{CO}_{2}$ concentrations are in the range of 5.1-7.0 and 19.1-22.7 (vol.\% dry), respectively. While at the locations where the measurements are carried out, the predicted values of $\mathrm{O}_{2}$ and $\mathrm{CO}_{2}$ concentrations are in the range of $3.8-10.0$ and $16.4-25.7$ (vol.\% dry), respectively.

In the upper calciner vessel (i.e., point 4-1), a slightly higher gas temperature is observed in the northern region of the cross-section both in the measurements and the CPFD predictions. The gas temperature from CPFD simulation is overpredicted. The measured gas temperature is in the range of $870-937^{\circ} \mathrm{C}$ while the predicted gas temper- 
ature at the location of point measurements is in the range of $903-1019^{\circ} \mathrm{C}$. The nonuniformity of the gas species concentration is still overpredicted. The measured $\mathrm{O}_{2}$ and $\mathrm{CO}_{2}$ concentrations are in the range of 3.0-4.5 and 25.7-29.3 (vol.\% dry), respectively. From the north to the south side, the measured $\mathrm{O}_{2}$ concentration decreases while the $\mathrm{CO}_{2}$ concentration increases. At locations where the measurements are carried out, the predicted values of $\mathrm{O}_{2}$ and $\mathrm{CO}_{2}$ concentrations are in the range of 3.4-5.4 and 25.8-30.6 (vol.\% dry), respectively.

In the swanneck and at measurement points 5-1 and 6-1, only the gas temperature is measured at different points over the cross-section. The predicted gas temperature is slightly higher and less uniform compared to the measured one. Overall, the gas temperature is overpredicted around 21 and $57^{\circ} \mathrm{C}$, respectively, at the measurement points $5-1$ and $6-1$.

Overprediction in non-uniformity of cross-sectional profiles of gas composition and temperature, can be attributed to several phenomena. Firstly, as no dispersion model is considered for particles, and as a consequence, particle dispersion level may be underpredicted (overprediction in the level of stratification). Furthermore, the effect of drag model on the dispersion of solid particles in a calciner at cold conditions has been reported to be important [60]. As it is stated earlier, the EMMS/matrix model used in the present study is based on fixed values for gas superficial velocity and solid mass flux while these parameters change along the calciner due to reactions as well as change in the crosssectional area of the calciner. Using a more advanced EMMS drag model may improve the non-uniformity of profiles. Finally, effective diffusivity in the gas species transport equation may be underpredicted due to underprediction of turbulent viscosity. This leads to high skewness degree in the gas species distributions over different cross-sections.

\subsection{Degree of fuel conversion and calcination}

In order to assess the progress of overall fuel oxidation and calcination reactions throughout the calciner, two parameters of fuel fraction converted, $F F C$, and calcination factor, $C F$, are calculated for both measurements and simulations and depicted in Fig. 
8. A complete description of the procedure for calculation of $F F C$ and $C F$ is provided in the supplementary material (section 4). The estimated values from the measurements are only provided at two cross-sections in the lower and upper calciner vessels. It can be stated that the fuel fraction converted, $F F C$, is slightly underpredicted by around 3.8$4.6 \%$ in the lower and upper calciner vessels. Nevertheless, the discrepancies in predicted values of $F F C$ lie in the degree of uncertainty of the values from the measurements. Predicted $F F C$, becomes almost constant in the swanneck with the final value of $95.0 \%$ at the exit of the calciner. The calcination factor, $C F$, is predicted by an acceptable degree of accuracy. The calcination reaction mainly takes place in the lower and upper calciner vessel and it progresses further in the swanneck, with the final predicted value of $C F$ being $96.4 \%$ at the exit of the calciner.

In order to better understand the progress of different processes in fuel conversion along the calciner, extents of consumption or release of $\mathrm{O}_{2}, \mathrm{CO}_{2}$, and $\mathrm{H}_{2} \mathrm{O}$ are presented in Fig. 9 (top). Also provided in this figure are the degree of conversion of individual fuel types along the calciner based on the remaining mass of combustibles in each fuel (middle plot) and the degree of calcination reaction and LOI (loss on ignition) for the raw meal particles fed to the upper and lower calciner vessels (bottom plot). Contour plots of time-averaged particle volume fraction, gas temperature, and gas $\mathrm{O}_{2}$ and $\mathrm{H}_{2} \mathrm{O}$ concentrations are shown in Fig. 10.

If it is assumed that complete fuel conversion and calcination take place in the calciner, according to the information provided in Table 3, the contribution of fuel moisture evaporation to the total $\mathrm{H}_{2} \mathrm{O}$ released in the calciner is around $34 \%$ and the rest is the product of methane oxidation. According to Fig. 9 (top), $\mathrm{H}_{2} \mathrm{O}$ is released mainly in the riser section, reduction zone, and the lower calciner vessel. In the middle of the reduction zone (approximately $31 \mathrm{~m}$ high), a smooth change in the slope of $\mathrm{H}_{2} \mathrm{O}$ release is observed that can be attributed to the completion of the moisture evaporation in SRF. However, some large SRF particles may still penetrate downstream of this location without being fully dried, mainly because of a slow heat transfer rate to them. The release of water 
vapor is completed at an approximate height of $53 \mathrm{~m}$ in the upper calciner vessel, indicating that the fuel moisture evaporation as well as the release and oxidation of volatiles is terminated at this location. The spacial distribution of water vapor in the gas can also be observed in Fig. 10. According to this plot, the release of water vapor is initially started in the riser section and then intensified in the conical section as a consequence of solid fuel moisture evaporation and volatiles (methane) oxidation. After the addition of tertiary air, $\mathrm{H}_{2} \mathrm{O}$ is diluted slightly and then starts to increase again before the constriction. Downstream of the constriction, the $\mathrm{H}_{2} \mathrm{O}$ concentration is diluted further.

The consumption of $\mathrm{O}_{2}$ (Fig. 9, top) is rapid in the lower calciner vessel and becomes slower in the upper vessel. In the swanneck, the oxygen consumption is almost negligible, in line with the progress of FFC in this area according to Fig. 8. Based on Fig. 9 (middle), in the reduction zone and the lower calciner vessel, individual solid fuel particles (i.e, petcoke and plastic and biomass fractions in SRF) are converted with almost the same mass loss rate with the only difference that the plastic conversion is almost completed at the exit of the lower calciner vessel (around 96\% conversion). In the upper calciner vessel and the swanneck, the conversion of biomass and petcoke particles takes place at a slower rate. At the exit of the calciner, petcoke is almost fully converted while the biomass overall conversion is around 97\%. This corresponds to around $95 \%$ of the oxygen required for complete fuel oxidation. It is important to mention at the calciner exit, the char conversion degree of the lighter biomass particles in SRF (i.e., terminal velocity below $3 \mathrm{~m} / \mathrm{s}$ ) is above $92 \%$ while for heavier biomass fractions (i.e., terminal velocity higher than $3 \mathrm{~m} / \mathrm{s}$ ), the char oxidation degree is in the range of $48-75 \%$. The lowest predicted char oxidation degree is around $48 \%$ for biomass particles belonging to a terminal velocity range of $5-7 \mathrm{~m} / \mathrm{s}$.

According to Table 3 and by assuming full fuel conversion and calcination reactions in the calciner, around $76 \%$ of the released $\mathrm{CO}_{2}$ is the contribution of calcination reaction while the rest is from fuel oxidation. At the exit of the lower calciner vessel, the overall fuel fraction converted, $F F C$, is above $84 \%$ and according to Fig. 9 (bottom), the calcination 
of the raw material fed to the lower calciner vessel is almost completed (calcination degree of around 96\%). Accordingly, it can be concluded that the amount of $\mathrm{CO}_{2}$ release in the lower calciner vessel stems from both calcination and fuel oxidation reactions while in the upper calciner vessel, $\mathrm{CO}_{2}$ is formed mainly from calcination. The rate of $\mathrm{CO}_{2}$ release is higher in the lower calciner vessel compared to the upper one, while in the swanneck, it is the slowest. At the exit of the calciner, the amount of released $\mathrm{CO}_{2}$ is approximately $95 \%$ of the nominal amount that can be released in the calciner, assuming full fuel conversion and calcination.

One of the important events that can be observed in Fig. 10 is high particle concentration regions near the walls, especially in the reduction zone, and lower and upper calciner vessels. This trend is further studied by presenting instantaneous locations of biomass, plastic and raw meal particles in Fig. 11. In the mentioned regions, solid particles travel with a slow pace either in the upward or the downward directions. The near-wall accumulation of particles provides them a longer residence time compared to other particles passing from core regions of the calciner. This behaviour is more pronounced in the conical section of the lower calciner vessel where the near wall biomass and plastic particles tend to travel in the downward direction. For raw meal particles, this behaviour is less noticeable. Accordingly, the calcination of raw meal particles increases the $\mathrm{CO}_{2}$ concentration and reduces the gas temperature in these regions (especially in the right side of lower calciner vessel). At the same time, due to the intensified moisture evaporation and devolatilization rates, the concentrations of water vapor and released volatiles are increased in the near wall regions. This is followed by partly oxidation of volatiles and substantial decrease of $\mathrm{O}_{2}$ concentration. In summary, the progress of calcination and fuel conversion processes is improved due to this behaviour.

\section{Conclusion}

A full-scale calciner operating with petcoke and SRF is studied by conducting CPFD simulation using Barracuda Virtual Reactor ${ }^{\circledR}$ software. The results from simulation are 
compared with extensive measurements of gas temperature and $\mathrm{O}_{2}$ and $\mathrm{CO}_{2}$ concentrations at different locations along the calciner. The gas $\mathrm{O}_{2}$ and $\mathrm{CO}_{2}$ concentrations are predicted with an acceptable degree of accuracy, while the gas temperature is overpredicted by around $50-150^{\circ} \mathrm{C}$. However, the overall trends in the gas temperature along the calciner are well-captured. A discussion regarding possible causes of discrepancies in the predicted gas temperature is provided. A comparison of the predicted cross-sectional profiles of $\mathrm{O}_{2}$ and $\mathrm{CO}_{2}$ and gas temperature with the measurements reveals that the overall trends are well-captured. However, for some of the cross-sections, an over-prediction in non-uniformity of the gas temperature and composition profiles is observed. The fuel fraction converted, $F F C$, is predicted with an acceptable degree of accuracy. Among different fuel types fed to the calciner, heavy biomass particles, i.e., particles with terminal velocity higher that $3 \mathrm{~m} / \mathrm{s}$, leave the calciner without complete combustion. These particles have a char oxidation degree in the range of $48-75 \%$ at the exit of the calciner. In the lower and upper calciner vessels, the calcination factor, $C F$, is well-predicted. It is shown that in the lower calciner vessel and specially the conical section, the biomass and plastic particles from SRF tend to accumulate near the calciner walls and generate a recirculation pattern. This increases their residence time and subsequently the corresponding fuel conversion degree.

\section{Acknowledgements}

This study was supported within the advanced technology platform "Minerals and Cement Process Technology - MiCeTech" funded by the Innovation Fund Denmark, FLSmidth A/S, Hempel and the Technical University of Denmark (Grant No. 39-2013-2). The authors are also grateful to Stephen Webb, Sam Clark, John Pendergrass, and other staff members of CPFD software in providing technical support. Also, the first author would like to thank the Sino-Danish Center for Education and Research for their support. 


\section{References}

[1] K. Baumert, J. Pershing, T. Herzog, Navigating the numbers: greenhouse gas data and international climate policy.

URL www . wri.org

[2] C. Bech, A. Mishulovich, Preheaters and precalciners, in: Innovations in Portland Cement Manufacturing, Portland Cement Association, Skokie, Illinoins, USA, 2004, pp. 269-286.

[3] W. Ariyaratne, M. Melaaen, L.-A. Tokheim, Determination of biomass fraction for partly renewable solid fuels, Energy 70 (2014) 465-472. doi:10.1016/j.energy. 2014.04.017.

[4] L. Nørskov, Combustion of solid alternative fuels in the cement kiln burner, Ph.D. thesis, Department of Chemical and Biochemical Engineering, Technical University of Denmark (2012).

[5] L. Diaz, G. Savage, L. Eggerth, Production of refuse derived fuel (RDF), in: Solid Waste Management, no. 1, United Nations Environment Programme, 2005, pp. 295302.

[6] R. Sarc, K. Lorber, R. Pomberger, M. Rogetzer, E. Sipple, Design, quality, and quality assurance of solid recovered fuels for the substitution of fossil feedstock in the cement industry, Waste Management and Research 32 (7) (2014) 565-585. doi: 10.1177/0734242X14536462.

[7] CEN/TC 343 - solid recovered fuels, Tech. rep., European Commette for Standardization (2012).

[8] M. Pedersen, Co-firing of alternative fuels in cement kiln burners, Phd thesis, Department of Chemical and Biochemical Engineering, Technical University of Denmark (2018). 
[9] F. Lockwood, J. Ou, Review: Burning refuse-derived fuel in a rotary cement kiln, Proceedings of the Institution of Mechanical Engineers, Part A: Journal of Power and Energy 207 (1) (1993) 65-70.

[10] B. Liedmann, S. Wirtz, V. Scherer, B. Krüger, Numerical study on the influence of operational settings on refuse derived fuel co-firing in cement rotary kilns, Energy Procedia 120 (2017) 254-261. doi:10.1016/j.egypro.2017.07.176.

[11] M. Agraniotis, N. Nikolopoulos, A. Nikolopoulos, P. Grammelis, E. Kakaras, Numerical investigation of Solid Recovered Fuels' co-firing with brown coal in large scale boilers: Evaluation of different co-combustion modes, Fuel 89 (12) (2010) 3693-3709. doi:10.1016/j.fuel.2010.07.030

[12] B. Liedmann, W. Arnold, B. Krüger, A. Becker, S. Krusch, S. Wirtz, V. Scherer, An approach to model the thermal conversion and flight behaviour of refuse derived fuel, Fuel 200 (2017) 252-271. doi:10.1016/j.fuel.2017.03.069.

[13] J. Maier, A. Gerhardt, G. Dunnu, Experiences on co-firing solid recovered fuels in the coal power sector, in: Solid Biofuels for Energy, 2011, pp. 75-94. doi:10.1007/ 978-1-84996-393-0_4.

[14] H. Wu, A. Pedersen, P. Glarborg, F. Frandsen, K. Dam-Johansen, B. Sander, Formation of fine particles in co-combustion of coal and solid recovered fuel in a pulverized coal-fired power station, Proceedings of the Combustion Institute 33 (2) (2011) 2845-2852. doi:10.1016/j.proci.2010.06.125

[15] H. Wu, M. Bashir, P. Jensen, B. Sander, P. Glarborg, Impact of coal fly ash addition on ash transformation and deposition in a full-scale wood suspension-firing boiler, Fuel 113 (2013) 632-643. doi:10.1016/j.fuel.2013.06.018.

[16] K. Theisen, E. Jøns, B. Osbøk, Cement clinkering: chemical and physical aspects, in: Innovations in Portland Cement Manufacturing, Portland Cement Association, Skokie, Illinoins, USA, 2011. 
[17] M. Bhatty, Cement kiln system buildups, in: I.C.S. proceedings, Columbus, Ohio, 1981, pp. 110-115.

[18] J. Johansen, P. Jensen, P. Glarborg, M. Mancini, R. Weber, R. Mitchell, Extension of apparent devolatilization kinetics from thermally thin to thermally thick particles in zero dimensions for woody biomass, Energy 95 (2016) 279-290. doi:10.1016/j . energy.2015.11.025.

[19] F. He, F. Behrendt, A new method for simulating the combustion of a large biomass particle: A combination of a volume reaction model and front reaction approximation, Combustion and Flame 158 (12) (2011) 2500-2511. doi:10.1016/j. combustflame.2011.04.016.

[20] K. Lorber, R. Sarc, A. Aldrian, Design and quality assurance for solid recovered fuel, Waste Management \& Research 30 (4) (2012) 370-380. doi:10.1177/ $0734242 X 12440484$

[21] H. Mikulčić, E. von Berg, M. Vujanović, X. Wang, H. Tan, N. Duić, Numerical evaluation of different pulverized coal and solid recovered fuel co-firing modes inside a large-scale cement calciner, Applied Energy 184 (2016) 1292-1305. doi:10.1016/ j.apenergy.2016.05.012.

[22] V. Mathiesen, T. Solberg, B. Hjertager, Predictions of gas-particle flow with an Eulerian model including a realistic particle size distribution, Powder Technology 112 (1-2) (2000) 34-45. doi:10.1016/S0032-5910(99)00303-4.

[23] M. A. Rizk, Mathematical modeling of densely loaded, particle-laden turbulent fLows, Automization and Sprays 3 (1) (1993) 1-27.

[24] M. Andrews, P. O'Rourke, The multiphase particle-in-cell (MP-PIC) method for dense particulate flows, International Journal of Multiphase Flow 22 (2) (1996) 379402. arXiv:arXiv:1011.1669v3, doi:10.1016/0301-9322(95)00072-0. 
[25] D. Snider, P. O'Rourke, The multiphase particle-in-cell (MP-PIC) method for dense particle flow, Computational Gas-Solids Flows and Reacting Systems: Theory, Methods and Practice, IGI Global, 2010. arXiv:arXiv:1011.1669v3, doi: $10.4018 / 978-1-61520-651-3 . \operatorname{ch} 009$

[26] D. Snider, S. Clark, P. O’Rourke, Eulerian-Lagrangian method for three-dimensional thermal reacting flow with application to coal gasifiers, Chemical Engineering Science 66 (6) (2011) 1285-1295. doi:10.1016/j.ces.2010.12.042

[27] Y. Jiang, G. Qiu, H. Wang, Modelling and experimental investigation of the fullloop gas-solid flow in a circulating fluidized bed with six cyclone separators, Chemical Engineering Science 109 (2014) 85-97. doi:10.1016/j.ces.2014.01.029.

[28] S. Kraft, F. Kirnbauer, H. Hofbauer, Influence of drag laws on pressure and bed material recirculation rate in a cold flow model of an $8 \mathrm{MW}$ dual fluidized bed system by means of CPFD, Particuology 36 (2018) 70-81. doi:10.1016/j.partic. 2017.04 .009

[29] S. Yang, H. Wu, W. Lin, H. Li, Q. Zhu, An exploratory study of three-dimensional MP-PIC-based simulation of bubbling fluidized beds with and without baffles, Particuology 39 (2018) 68-77. doi:10.1016/j.partic.2017.10.003

[30] D. Fidaros, C. Baxevanou, C. Dritselis, N. Vlachos, Numerical modelling of flow and transport processes in a calciner for cement production, Powder Technology 171 (2) (2007) 81-95. doi:10.1016/j.powtec.2006.09.011

[31] L. Huang, J. Lu, S. Wang, Z. Hu, Numerical simulation of pollutant formation in precalciner, The Canadian Journal of Chemical Engineering 83 (4) (2008) 675-684. doi:10.1002/cjce.5450830408.

[32] Z. Hu, J. Lu, L. Huang, S. Wang, Numerical simulation study on gas-solid two-phase flow in pre-calciner, Communications in Nonlinear Science and Numerical Simulation 11 (3) (2006) 440-451. doi:10.1016/j.cnsns.2004.07.004. 
[33] Z. Ghizdavet, A. Volceanov, A. Semenescu, CFD simulations of gases flow in calciners, Revista de Chimie 59 (5) (2008) 511-514.

[34] H. Mikulčić, M. Vujanović, D. Fidaros, P. Priesching, I. Minić, R. Tatschl, N. Duić, G. Stefanović, The application of CFD modelling to support the reduction of CO2 emissions in cement industry, Energy 45 (1) (2012) 464-473. doi:10.1016/j. energy.2012.04.030.

[35] H. Mikulčić, E. Von Berg, M. Vujanović, P. Priesching, R. Tatschl, N. Duić, Numerical analysis of cement calciner fuel efficiency and pollutant emissions, Clean Technologies and Environmental Policy 15 (3) (2013) 489-499. doi:10.1007/ s10098-013-0607-5.

[36] H. Mikulčić, M. Vujanović, N. Duić, Reducing the CO2 emissions in Croatian cement industry, Applied Energy 101 (2013) 41-48. doi:10.1016/j.apenergy.2012.02. 083.

[37] H. Mikulčić, M. Vujanović, N. Duić, Improving the sustainability of cement production by using numerical simulation of limestone thermal degradation and pulverized coal combustion in a cement calciner, Journal of Cleaner Production 88 (0) (2015) 262-271. doi:10.1016/j.jclepro.2014.04.011.

[38] M. Zeneli, A. Nikolopoulos, N. Nikolopoulos, P. Grammelis, S. Karellas, E. Kakaras, Simulation of the reacting flow within a pilot scale calciner by means of a three phase TFM model, Fuel Processing Technology 162 (2017) 105-125. doi:10.1016/ j.fuproc.2017.03.032.

[39] L. Huanpeng, L. Wentie, Z. Jianxiang, J. Ding, Z. Xiujian, L. Huilin, Numerical study of gas-solid flow in a precalciner using kinetic theory of granular flow, Chemical Engineering Journal 102 (2) (2004) 151-160. doi:10.1016/j.cej.2004.03.004.

[40] Z. Jianxiang, L. Huilin, S. Xiaoquan, H. Yurong, D. Jianmin, W. Shuyan, Hydro- 
dynamic modeling of gas-particle flows in D-D calciners, Industrial \& Engineering Chemistry Research 44 (9) (2005) 3033-3041. doi:10.1021/ie040168j.

[41] J. Xie, S. Mei, Numerical simulation of gas-solid flow in a precalciner of cement industry, Materials Science Forum 575-578 (2008) 1234-1239. doi:10.4028/www. scientific.net/MSF.575-578.1234.

[42] X. Li, B. Ma, Z. Hu, Computational modeling of aerodynamic characteristics in sprayed and spiraled precalciner, Communications in Nonlinear Science and Numerical Simulation 13 (6) (2008) 1205-1211. doi:10.1016/j.cnsns.2006.10.002.

[43] H. Luo, Modeling the gas-solid flow in calcining furnace, The Journal of Computational Multiphase Flows 3 (1) (2011) 1-12. doi:10.1260/1757-482X.3.1.1.

[44] N. Xing, W. Zhao, Numerical simulation of the gas-solid two-phase flow in the cement precalciner based on fluent software, Advanced Materials Research 255-260 (6) (2011) 4232-4236. doi:10.4028/www.scientific.net/AMR.255-260.4232.

[45] J. Zheng, Y. Wang, X. Zhu, Hydrodynamic modelling of gas and solid flows in the pre-calciner, in: 2012 Asia-Pacific Power and Energy Engineering Conference, IEEE, 2012, pp. 1-4. doi:10.1109/APPEEC.2012.6307057.

[46] D. Giddings, C. Eastwick, S. Pickering, K. Simmons, Computational fluid dynamics applied to a cement precalciner, Proceedings of the Institution of Mechanical Engineers, Part A: Journal of Power and Energy 214 (3) (2000) 269-280. doi:10.1243/0957650001538353

[47] S. Oh, D. Kim, J. Yoon, S. Byun, W. Kwon, S. Kim, H. Kim, Numerical analysis of turbulent gas-particle flow and coal combustion in a fluidized-bed calciner, Journal of Industrial and Engineering Chemistry 10 (2) (2004) 208-214.

[48] L. Huang, J. Lu, F. Xia, W. Li, H. Ren, 3-D mathematical modeling of an in-line 
swirl-spray precalciner, Chemical Engineering and Processing: Process Intensification 45 (3) (2006) 204-213. doi:10.1016/j.cep.2005.09.001.

[49] S. Oh, C. Jin, J. Hong, W. Kwon, S. Kim, The behavior of automobile shredder residue chips in a precalciner for cement manufacturing process, Materials Science Forum 544-545 (2007) 885-888. doi:10.4028/www. scientific.net/MSF. 544-545. 885.

[50] H. Mikulčić, E. Von Berg, M. Vujanović, P. Priesching, R. Tatschl, N. Duić, CFD analysis of a cement calciner for a cleaner cement production, Chemical Engineering Transactions 29 (2012) 1513-1518. doi:10.3303/CET1229253.

[51] S. Mei, J. Xie, X. Chen, F. He, H. Yang, M. Jin, Numerical simulation of the complex thermal processes in a vortexing precalciner, Applied Thermal Engineering 125 (2017) 652-661. doi:10.1016/j.applthermaleng.2017.07.041.

[52] D. Giddings, S. Pickering, K. Simmons, C. Eastwick, Combustion and aerodynamic behaviour of car tyre chips in a cement works precalciner, Journal of the Institute of Energy 75 (504) (2002) 91-99.

[53] H. Mikulčić, E. von Berg, M. Vujanović, N. Duić, Numerical study of co-firing pulverized coal and biomass inside a cement calciner, Waste Management \& Research 32 (7) (2014) 661-669. doi:10.1177/0734242X14538309.

[54] T. Bluhm-Drenhaus, S. Wirtz, V. Scherer, S. Perumalsamy, G. Oeljeklaus Habil, K. Görner, Z. Asian, S. Schäfer, V. Hoenig, CFD simulation of the co-incineration of solid recovered fuels in the precalciner, Cement International 9 (3) (2011) 54-63.

[55] M. Nakhaei, M. Pedersen, H. Wu, L. Jensen, P. Glarborg, P. Jensen, D. Grévain, K. Dam-Johansen, Aerodynamic and Physical Characterization of Refuse Derived Fuel, Energy \& Fuels 32 (7) (2018) 7685-7700. doi:10.1021/acs.energyfuels. 8b01359. 
[56] M. Nakhaei, H. Wu, D. Grévain, L. Jensen, P. Glarborg, S. Clausen, K. DamJohansen, Experiments and modeling of single plastic particle conversion in suspension, Fuel Processing Technology 178 (2018) 213-225. doi:10.1016/j.fuproc. 2018.05 .003

[57] FLSmidth, Cement kiln inlet gas analysis - KilnLoq (2015). URL WwW.flsmidth.com/en-US/Industries/Categories/Products/Gas+ Analysis/Product+Program/Process+Gas+Analysis/Process+Gas+Analysis

[58] C. Chen, J. Werther, S. Heinrich, H. Qi, E. Hartge, CPFD simulation of circulating fluidized bed risers, Powder Technology 235 (2013) 238-247. doi:10.1016/j . powtec.2012.10.014.

[59] Y. Wu, L. Peng, L. Qin, M. Wang, J. Gao, X. Lan, Validation and application of CPFD models in simulating hydrodynamics and reactions in riser reactor with Geldart A particles, Powder Technology 323 (2018) 269-283. doi:10.1016/j.powtec. 2017.10 .003

[60] M. Nakhaei, C. Hessel, H. Wu, D. Grévain, S. Zakrzewski, L. Jensen, P. Glarborg, K. Dam-Johansen, Experimental and CPFD study of gas-solid flow in a cold pilot calciner, Powder Technology 340 (2018) 99-115. doi:10.1016/j.powtec.2018.09. 008 .

[61] M. Feng, F. Li, W. Wang, J. Li, Parametric study for MP-PIC simulation of bubbling fluidized beds with Geldart A particles, Powder Technology 328 (2018) 215-226. doi:10.1016/j.powtec.2018.01.024.

[62] W. Ariyaratne, C. Ratnayake, M. Melaaen, Application of the MP-PIC method for predicting pneumatic conveying characteristics of dilute phase flows, Powder Technology 310 (2017) 318-328. doi:10.1016/j.powtec.2017.01.048.

[63] J. Smagorinsky, General circulation experiments with the primitive equations, 
[64] C. Wen, Y. Yu, Mechanics of fluidization, in: Chemical Engineering Progress, Symposium Series, Vol. 62, 1966, pp. 100-111.

[65] M. Patel, K. Pericleous, M. Cross, Numerical modelling of circulating fluidized beds, International Journal of Computational Fluid Dynamics 1 (2) (1993) 161-176. doi: $10.1080 / 10618569308904470$.

[66] G. Ganser, A rational approach to drag prediction of spherical and nonspherical particles, Powder Technology 77 (2) (1993) 143-152. doi:10.1016/0032-5910(93) 80051-B.

[67] K. Hong, Z. Shi, W. Wang, J. Li, A structure-dependent multi-fluid model (SFM) for heterogeneous gas-solid flow, Chemical Engineering Science 99 (2013) 191-202. doi:10.1016/j.ces.2013.05.050.

[68] J. Li, W. Ge, W. Wang, N. Yang, X. Liu, L. Wang, X. He, X. Wang, J. Wang, M. Kwauk, From multiscale modeling to meso-science, Springer Berlin Heidelberg, Berlin, Heidelberg, 2013. doi:10.1007/978-3-642-35189-1.

[69] V. Jiradilok, D. Gidaspow, S. Damronglerd, W. Koves, R. Mostofi, Kinetic theory based CFD simulation of turbulent fluidization of FCC particles in a riser, Chemical Engineering Science 61 (17) (2006) 5544-5559. doi:10.1016/j.ces.2006.04.006.

[70] C. Westbrook, F. Dryer, Simplified reaction mechanisms for the oxidation of hydrocarbon fuels in flames, Combustion Science and Technology 27 (1-2) (1981) 31-43. arXiv:arXiv:1011.1669v3, doi:10.1080/00102208108946970.

[71] F. Dryer, I. Glassman, High-temperature oxidation of CO and CH4, Symposium (International) on Combustion 14 (1) (1973) 987-1003. doi:10.1016/S0082-0784(73) 80090-6. 
[72] N. Hu, A. Scaroni, Calcination of pulverized limestone particles under furnace injection conditions, Fuel 75 (2) (1996) 177-186. doi:10.1016/0016-2361(95)00234-0.

[73] R. Borgwardt, Calcination kinetics and surface area of dispersed limestone particles, AIChE Journal 31 (1) (1985) 103-111. doi:10.1002/aic.690310112.

[74] B. Young, I. Smith, The kinetics of combustion of petroleum coke particles at 1000 to $1800 \mathrm{~K}$ : The reaction order, Symposium (International) on Combustion 18 (1) (1981) 1249-1255. doi:10.1016/S0082-0784(81)80128-2.

[75] T. Linjewile, V. Gururajan, P. Agarwal, Measurement and modelling of the temperature of burning petroleum coke particles in an incipiently fluidized bed, Fuel 72 (6) (1993) 813-819. doi:10.1016/0016-2361(93)90085-G.

[76] I. Smith, The combustion rates of coal chars: A review, Symposium (International) on Combustion 19 (1) (1982) 1045-1065. doi:10.1016/S0082-0784(82)80281-6.

[77] M. Field, D. Gill, B. Morgan, P. Hawksley, Combustion of pulverised coal, BCURA, 1967.

[78] K. M. Bryden, M. J. Hagge, Modeling the combined impact of moisture and char shrinkage on the pyrolysis of a biomass particle, Fuel 82 (13) (2003) 1633-1644. doi:10.1016/S0016-2361(03)00108-X.

[79] G. Agarwal, B. Lattimer, Method for measuring the standard heat of decomposition of materials, Thermochimica Acta 545 (2012) 34-47. doi:10.1016/j.tca.2012. 06.027 .

[80] Q. Xiong, F. Xu, E. Ramirez, S. Pannala, C. S. Daw, Modeling the impact of bubbling bed hydrodynamics on tar yield and its fluctuations during biomass fast pyrolysis, Fuel 164 (2016) 11-17. doi:10.1016/j.fuel.2015.09.074. 
[81] Q. Xiong, S. Kong, High-Resolution Particle-Scale Simulation of Biomass Pyrolysis, ACS Sustainable Chemistry \& Engineering 4 (10) (2016) 5456-5461. doi:10.1021/ acssuschemeng. 6b01020.

[82] Q. Xiong, Y. Yang, F. Xu, Y. Pan, J. Zhang, K. Hong, G. Lorenzini, S. Wang, Overview of Computational Fluid Dynamics Simulation of Reactor-Scale Biomass Pyrolysis, ACS Sustainable Chemistry \& Engineering 5 (4) (2017) 2783-2798. doi: 10.1021/acssuschemeng. 6b02634.

[83] H. Zhong, Q. Xiong, Y. Zhu, S. Liang, J. Zhang, B. Niu, X. Zhang, CFD modeling of the effects of particle shrinkage and intra-particle heat conduction on biomass fast pyrolysis, Renewable Energy 141 (2019) 236-245. doi:10.1016/j.renene.2019. 04.006 .

[84] H. Zhong, F. Xu, J. Zhang, Y. Zhu, S. Liang, B. Niu, X. Zhang, Variation of Geldart classification in MFM simulation of biomass fast pyrolysis considering the decrease of particle density and diameter, Renewable Energy 135 (2019) 208-217. doi:10. $1016 / j . r e n e n e .2018 .11 .097$

[85] A. Bharadwaj, L. Baxter, A. Robinson, Effects of intraparticle heat and mass transfer on biomass devolatilization: experimental results and model predictions, Energy \& Fuels 18 (4) (2004) 1021-1031. doi:10.1021/ef0340357.

[86] D. Evans, H. Emmons, Combustion of wood charcoal, Fire Safety Journal 1 (1) (1977) 57-66. doi:10.1016/0379-7112(77)90008-X.

[87] C. Di Blasi, F. Buonanno, C. Branca, Reactivities of some biomass chars in air, Carbon 37 (8) (1999) 1227-1238. doi:10.1016/S0008-6223(98)00319-4.

[88] M. Momeni, C. Yin, S. Kær, T. Hansen, P. Jensen, P. Glarborg, Experimental study on effects of particle shape and operating conditions on combustion characteristics of single biomass particles, Energy \& Fuels 27 (1) (2013) 507-514. doi:10.1021/ ef301343q. 
[89] P. Mason, L. Darvell, J. Jones, M. Pourkashanian, A. Williams, Single particle flamecombustion studies on solid biomass fuels, Fuel 151 (2015) 21-30. doi:10.1016/j. fuel.2014.11.088.

[90] Z. Lu, J. Jian, P. Jensen, H. Wu, P. Glarborg, Influence of torrefaction on single particle combustion of wood, Energy \& Fuels 30 (7) (2016) 5772-5778. doi:10. 1021/acs.energyfuels.6b00806.

[91] A. Amsden, T. Butler, P. O'Rourke, The KIVA-II computer program for transient multidimensional chemically reactive flows with sprays, in: SAE Technical Papers, 1987. doi:10.4271/872072.

[92] T. Anderson, R. Jackson, Fluid mechanical description of fluidized beds, equations of motion, Industrial \& Engineering Chemistry Fundamentals 6 (4) (1967) 527-539. doi:10.1021/i160024a007.

[93] R. Jackson, The dynamics of fluidized particles, Cambridge University Press, Cambridge, UK, 2000.

[94] P. O'Rourke, Collective drop effects on vaporizing liquid sprays, Ph.D. thesis, Department of Mechanical and Aerospace Engineering, Princeton University (1981).

[95] S. Harris, D. Crighton, Solitons, solitary waves, and voidage disturbances in gasfluidized beds, Journal of Fluid Mechanics 266 (1) (1994) 243. doi:10.1017/ S0022112094000996.

[96] W. Ranz, W. Marshall, Evaporation from drops, Chemical Engineering Progress 48 (141) (1952) $141-148$.

[97] M. Larsen, Alternative fuels in cement production, Ph.D. thesis, Department of Chemical and Biochemical Engineering, Technical University of Denmark (2007). 


\section{${ }_{973}$ Tables}

Table 1: Ultimate and proximate analysis of petcoke and SRF fired in the studied calciner.

\begin{tabular}{lcc}
\hline Parameter & petcoke & SRF \\
\hline LHV $^{a}(k J / k g)$ & 33.2 & 14.0 \\
proximate analysis & \\
Moisture content $(w t . \%)$ & 0.9 & 25.0 \\
Volatile matter $(w t . \%)$ & 11.8 & 55.0 \\
Fixed carbon $(w t . \%)$ & 84.6 & 7.2 \\
Ash content $(w t . \%)$ & 2.7 & 12.8 \\
\hline & ultimate analysis ${ }^{b}$ & \\
C $(w t . \%)$ & 84.7 & 36.7 \\
H $(w t . \%)$ & 3.5 & 5.2 \\
S $(w t . \%)$ & 5.0 & 0.4 \\
$\mathrm{~N}(w t . \%)$ & 1.9 & 0.6 \\
O $(w t . \%)$ & 1.3 & 19.3 \\
\hline
\end{tabular}

\footnotetext{
${ }^{a}$ Lower heating value at $0^{\circ} \mathrm{C}$

${ }^{b}$ As-received basis
} 
Table 2: Eulerian and Lagrangian equations of the gas flow and solid particles in the full-scale reactive calciner.

Eulerian equations of the carrier gas [26, 92, 93]

Continuity equation $\quad \frac{\partial \theta_{g} \rho_{g}}{\partial t}+\nabla \cdot\left(\theta_{g} \rho_{g} \mathbf{u}_{g}\right)=\delta \dot{m}_{p}$

Momentum equations $\quad \frac{\left(\partial \theta_{g} \rho_{g} \mathbf{u}_{g}\right)}{\partial t}+\nabla \cdot\left(\theta_{g} \rho_{g} \mathbf{u}_{g} \mathbf{u}_{g}\right)=-\nabla P-\mathbf{F}_{p}+\theta_{g} \rho_{g} \mathbf{g}+\nabla \cdot\left(\theta_{g} \boldsymbol{\tau}_{g}\right)$

$$
\frac{\left(\partial \theta_{g} \rho_{g} h_{g}\right)}{\partial t}+\nabla \cdot\left(\theta_{g} \rho_{g} h_{g} \mathbf{u}_{g}\right)=-F_{T p}+\nabla \cdot\left(\theta_{g} \mathbf{u}_{g} \cdot \boldsymbol{\tau}_{g}\right)-\nabla \cdot
$$

Energy equation 94 ]

$$
\left(-\theta_{g} \kappa_{e f f} \nabla T_{g}\right)+\dot{q}_{D}+\dot{Q}_{g}
$$

Transport equation for

species $i$

$$
\frac{\left(\partial \theta_{g} \rho_{g} Y_{g, i}\right)}{\partial t}+\nabla \cdot\left(\theta_{g} \rho_{g} Y_{g, i} \mathbf{u}_{g}\right)=\nabla \cdot\left(\theta_{g} \rho_{g} D_{t} \nabla Y_{g, i}\right)+\delta \dot{m}_{i, c h e m}
$$

Fluid stress tensor

Turbulent viscosity 63

$$
\tau_{g_{i j}}=\mu_{e f f}\left(\frac{\partial u_{g_{i}}}{\partial x_{j}}+\frac{\partial u_{g_{j}}}{\partial x_{i}}\right)-\frac{2}{3} \mu_{e f f} \delta_{i j} \frac{\partial u_{g_{k}}}{\partial x_{k}}
$$

Effective viscosity

$$
\mu_{t}=C_{S}^{2} \rho_{g} \Delta^{2} \sqrt{\left(\frac{\partial u_{g_{i}}}{\partial x_{j}}+\frac{\partial u_{g_{j}}}{\partial x_{i}}\right)^{2}}
$$

Enthalpy diffusion term

$\mu_{e f f}=\mu_{g}+\mu_{t}$

$$
\dot{q_{D}}=\sum_{i=1}^{N_{s}} \nabla \cdot\left(\theta_{g} \rho_{g} h_{g, i} D_{t} \nabla Y_{g, i}\right)
$$

Effective thermal conduc-

tivity

$$
\kappa_{e f f}=\kappa_{g}+\frac{C p_{g} \mu_{t}}{P r_{t}}
$$

Turbulent diffusivity

$$
D_{t}=\frac{\mu_{t}}{\rho_{g} S c_{t}}
$$

Lagrangian equations of particles

Particle acceleration 25] $\dot{\mathbf{u}}_{p}=\frac{d \mathbf{u}_{p}}{d t}=\frac{R e_{p} C_{D}}{24 \tau_{p}}\left(\mathbf{u}_{g \odot p}-\mathbf{u}_{p}\right)-\frac{1}{\rho_{p}} \nabla P_{\odot p}+\mathbf{g}-$ $\frac{1}{\theta_{p} \rho_{p}} \nabla \tau_{N S \odot p}$

Particle velocity 25]

$$
\mathbf{u}_{p}=\frac{d \mathbf{x}_{p}}{d t}
$$

Particle normal stress 25

95

$$
\tau_{N S}=\frac{P_{s} \theta_{p}^{\beta}}{\max \left(\theta_{C P}-\theta_{p}, 0\right)+\epsilon\left(1-\theta_{p}\right)}
$$

Particle temperature

$$
\frac{d T_{p}}{d t}=\frac{N u_{p}}{2 \phi \tau_{T}}\left[\left(T_{g \odot p}-T_{p}\right)+\epsilon_{p} \sigma \frac{d_{p}}{N u_{p} \kappa_{g}}\left(T_{e n v}^{4}-T_{p}^{4}\right)\right]+\frac{\dot{Q}_{p}}{m_{p} C_{p_{p}}}
$$

Particle Nusselt number

$$
N u_{p}=2.0+0.6 \operatorname{Re}_{p}^{\frac{1}{2}} \operatorname{Pr}_{g}^{\frac{1}{3}}
$$


Table 3: Simulation boundary conditions for the studied calciner system. The heating value, moisture, volatile, fixed carbon, and ash contents of petcoke and SRF are from the fuel analysis.

\begin{tabular}{|c|c|c|c|c|c|c|}
\hline Production & \multicolumn{4}{|c|}{ Fuels used (energy basis) } & Bypass & $\begin{array}{c}\text { Excess air, } \\
\lambda\end{array}$ \\
\hline 3488 tpd & \multicolumn{4}{|c|}{$85.0 \% \mathrm{SRF}+15.0 \%$ petcoke } & $7.0 \%$ & 1.38 \\
\hline \multicolumn{7}{|c|}{ Gas composition } \\
\hline \multirow[t]{2}{*}{ Inlet name } & \multirow{2}{*}{$\begin{array}{c}\text { Mass flow rate } \\
\qquad(\mathrm{kg} / \mathrm{s})\end{array}$} & \multirow{2}{*}{$\begin{array}{c}\text { Temperature } \\
\qquad(K)\end{array}$} & \multicolumn{4}{|c|}{ Composition (vol.\% wet) } \\
\hline & & & $\mathrm{H}_{2} \mathrm{O}$ & $\mathrm{O}_{2}$ & $\mathrm{CO}_{2}$ & $\mathrm{~N}_{2}$ \\
\hline Kiln inlet & 30.6 & 1410 & 5.6 & 7.4 & 11.1 & 75.9 \\
\hline Bypass & 2.1 & 1410 & 5.6 & 7.4 & 11.1 & 75.9 \\
\hline TAD & 29.4 & 1099 & 0.8 & 20.7 & 0.0 & 78.5 \\
\hline Transport air & 1.7 & 293 & 0.8 & 20.7 & 0.0 & 78.5 \\
\hline \multirow{3}{*}{ Inlet name } & \multicolumn{5}{|c|}{ Raw meal + dust properties } & \\
\hline & Mass flow rate & \multirow{2}{*}{$\begin{array}{l}\text { Temperature } \\
\qquad(K)\end{array}$} & \multicolumn{4}{|c|}{ Composition (wt.\%) } \\
\hline & $(k g / s)$ & & $\mathrm{CaO}$ & $\mathrm{CaCO}_{3}$ & inert & $\mathrm{LOI}^{a}(\%)$ \\
\hline Dust to riser & 6.8 & 1410 & 100.0 & 0.0 & 0.0 & 0.0 \\
\hline Dust to TAD & 1.5 & 1099 & 100.0 & 0.0 & 0.0 & 0.0 \\
\hline $\begin{array}{l}\text { Meal to lower } \\
\text { calciner }\end{array}$ & 42.7 & 1114 & 12.3 & 63.2 & 24.5 & 27.8 \\
\hline $\begin{array}{l}\text { Meal to upper } \\
\text { calciner }\end{array}$ & 31.5 & 992 & 1.6 & 75.8 & 22.6 & 33.7 \\
\hline \multirow{3}{*}{ Inlet name } & \multicolumn{5}{|c|}{ Fuel properties } & \\
\hline & Heating value ${ }^{b}$ & mass flow rate & \multicolumn{4}{|c|}{ composition (wt.\%) } \\
\hline & $(k J / k g)$ & $(k g / s)$ & moisture & ash & $\begin{array}{c}\text { fixed } \\
\text { carbon }\end{array}$ & vol. \\
\hline RDF-overall & 16468 & 4.3 & 27.6 & 14.0 & 8.5 & 49.9 \\
\hline RDF-biomass & 8231 & 3.0 & 35.8 & 11.0 & 12.2 & 41.0 \\
\hline RDF-plastic & 41877 & 1.1 & 10.0 & 6.0 & 0.0 & 84.0 \\
\hline RDF-inert & -122 & 0.2 & 5.0 & 95.0 & 0.0 & 0.0 \\
\hline Petcoke & 33230 & 0.4 & 0.9 & 2.7 & 84.6 & 11.8 \\
\hline
\end{tabular}

${ }^{a}$ Loss on ignition (measured from samples taken during from the plant).

${ }^{b}$ Wet basis lower heating value at $0^{\circ} \mathrm{C}$. 
Figure Captions

Figure 1. Schematic representation of the studied in-line calciner (ILC) system with a high temperature split along with the cross-sections at which the measurements are carried out. The figure is modified and reproduced from [97].

Figure 2. Overview of the studied calciner geometry along with the location of boundary conditions.

Figure 3. Area-averaged and mass flow-averaged $\mathrm{O}_{2}$ and $\mathrm{CO}_{2}$ concentrations of dry gas predicted from CPFD simulations and compared with the measured values along the calciner. The symbols and errorbars represent arithmetic average and maximum/minimum (time-averaged) values of the point measurements in each cross-section. The discontinuity in the area-average curve corresponds to the turning region of swanneck.

Figure 4. Area-averaged and mass flow-averaged gas temperature predicted from CPFD simulation and compared with full-scale measurement values along the calciner. The symbols and errorbars represent arithmetic average and maximum/minimum (time-averaged) values of the point measurements in each cross-section. The discontinuity in the areaaverage curve corresponds to the turning region of swanneck.

Figure 5. Spacial distributions of gas temperature and species concentrations predicted from CPFD simulation and compared with the full-scale measurements at points 1-2 (left) and 2-1 (right).

Figure 6. Spacial distributions of gas temperature and species concentrations predicted from CPFD simulation and compared with the full-scale measurements at points 3-1 (left) and 4-1 (right).

Figure 7. Spacial distributions of gas temperature predicted from CPFD simulation and compared with full-scale measurements at points 5-1 (left) and 6-1 (right).

Figure 8. Fuel fraction converted $(F F C)$ and calcination factor $(C F)$ predicted from the CPFD simulation and compared with the estimated values from the measurements along the calciner. The symbols and errorbars represent arithmetic average and maximum/minimum (time-averaged) values of the point measurements in each cross-section.

Figure 9. Predicted extents of $\mathrm{O}_{2}$ consumption and $\mathrm{CO}_{2}$ and $\mathrm{H}_{2} \mathrm{O}$ production (top), individual fuel conversion degrees based on the time-averaged mass flow rate of particles 
1005

1006

1007

1008

1009

1010

1011 Figure 11. Example of an instantaneous distribution of biomass (left), plastic (middle),

1012

1013

1014

passing through different cross-sections (middle), and the calcination degree and LOI of raw meal particles based on the time-averaged mass flow rates of particles passing through different cross-sections (bottom), along the calciner.

Figure 10. Predicted spacial distribution of time-averaged particle volume fraction, gas temperature, and gas $\mathrm{O}_{2}$ and $\mathrm{H}_{2} \mathrm{O}$ concentrations, respectively from left to right, along calciner height. and raw meal (right) particle clouds from the CPFD simulation in a vertical slice of the calciner. The upward and downward moving particles are shown as red and blue colors, respectively. 


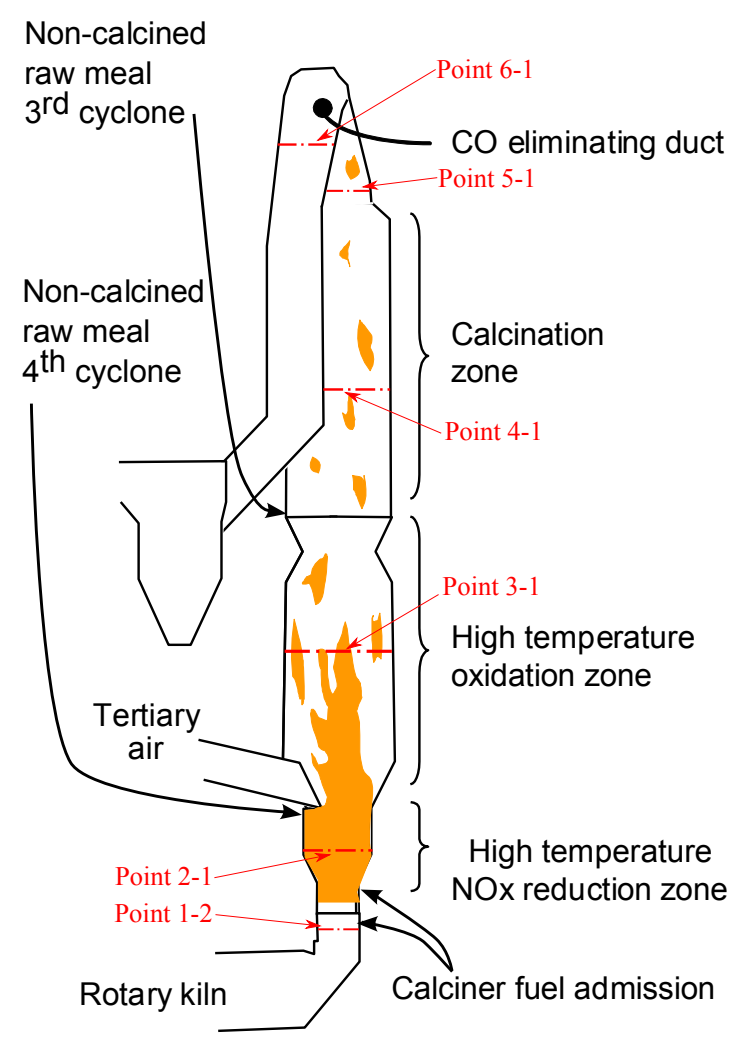

Figure 1: Schematic representation of the studied in-line calciner (ILC) system with a high temperature split along with the cross-sections at which the measurements are carried out. The figure is modified and reproduced from 97 . 


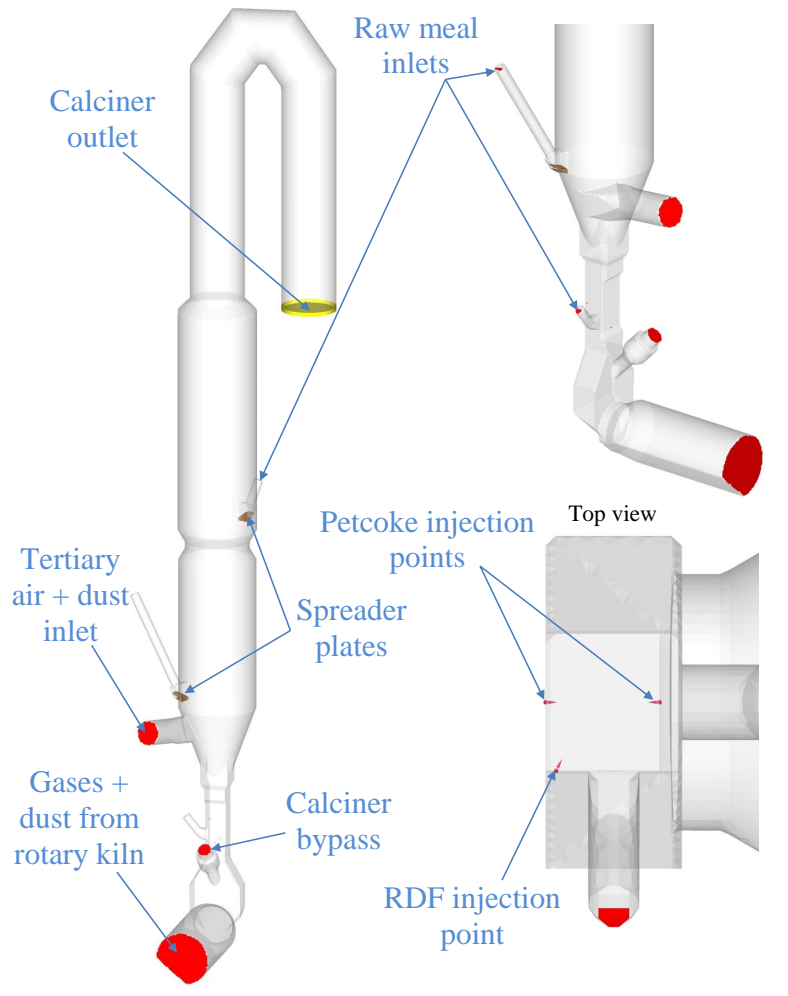

Figure 2: Overview of the studied calciner geometry along with the location of boundary conditions. 


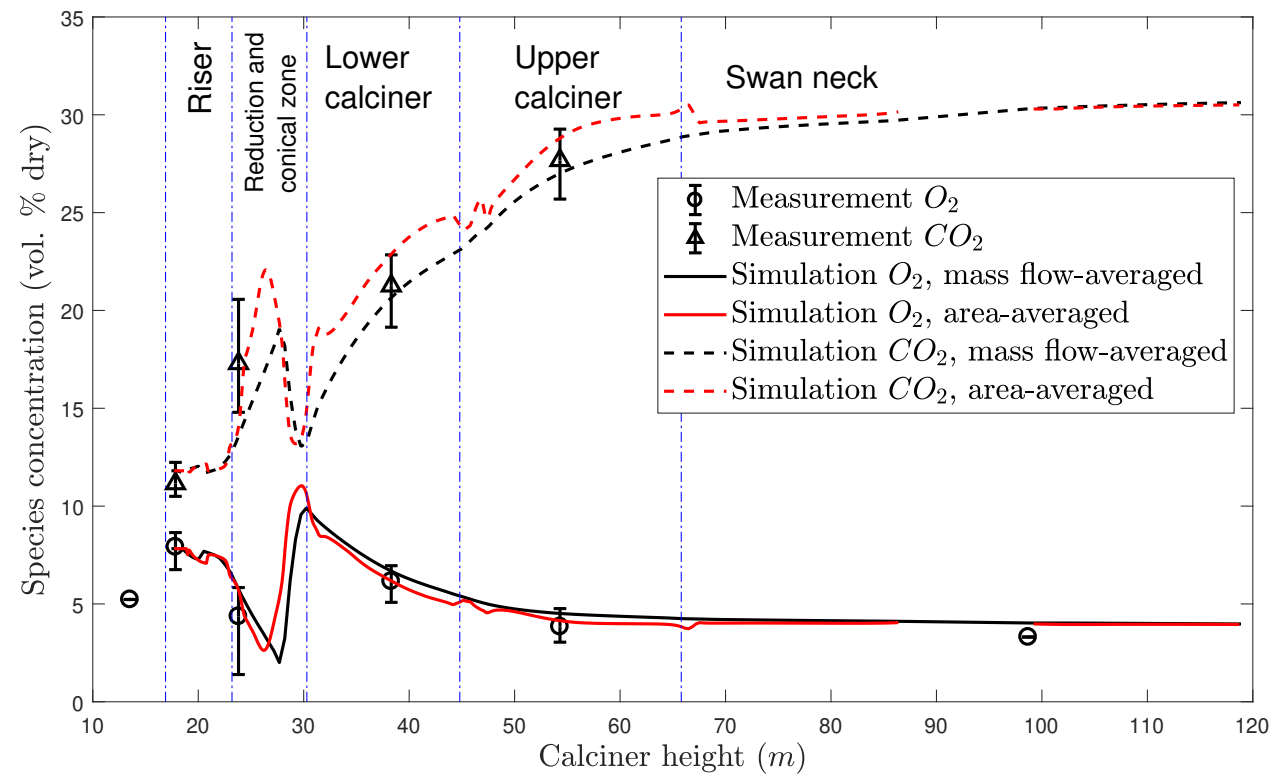

Figure 3: Area-averaged and mass flow-averaged $\mathrm{O}_{2}$ and $\mathrm{CO}_{2}$ concentrations of dry gas predicted from CPFD simulations and compared with the measured values along the calciner. The symbols and errorbars represent arithmetic average and maximum/minimum (time-averaged) values of the point measurements in each cross-section. The discontinuity in the area-average curve corresponds to the turning region of swanneck.

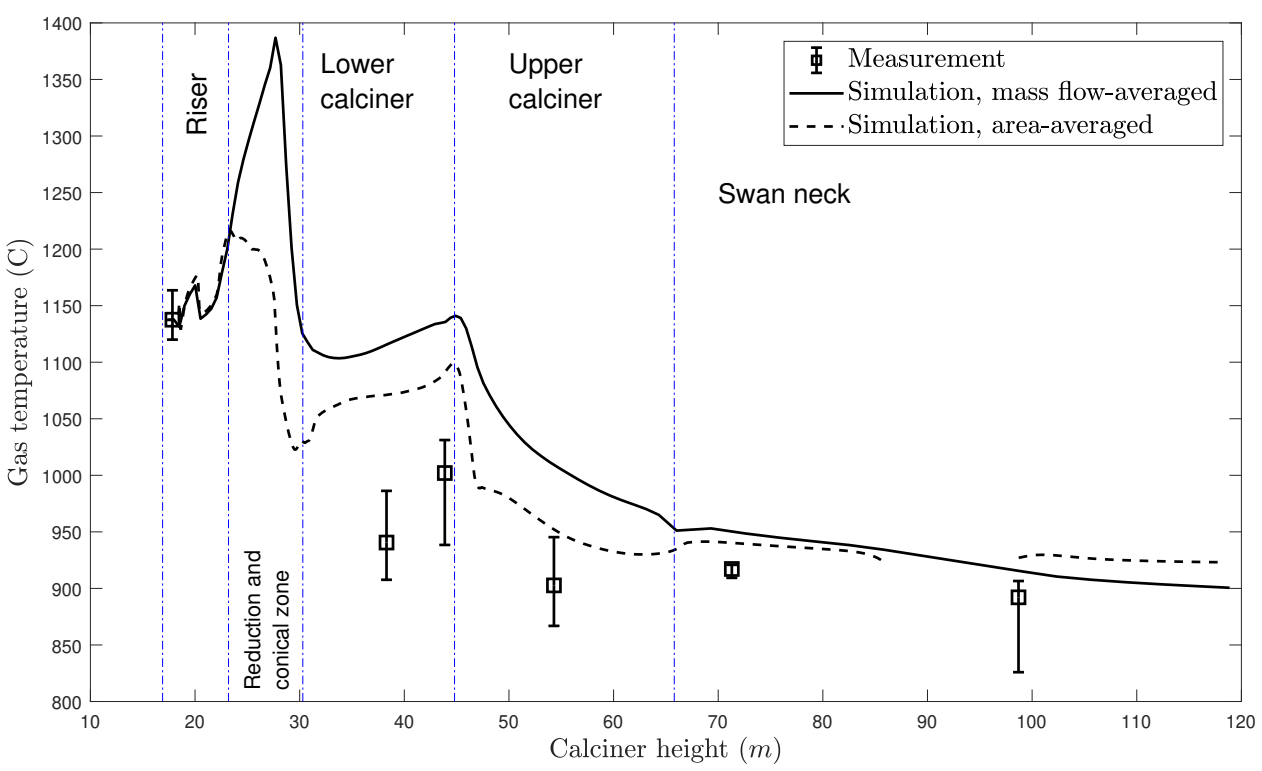

Figure 4: Area-averaged and mass flow-averaged gas temperature predicted from CPFD simulation and compared with full-scale measurement values along the calciner. The symbols and errorbars represent arithmetic average and maximum/minimum (time-averaged) values of the point measurements in each cross-section. The discontinuity in the area-average curve corresponds to the turning region of swanneck. 

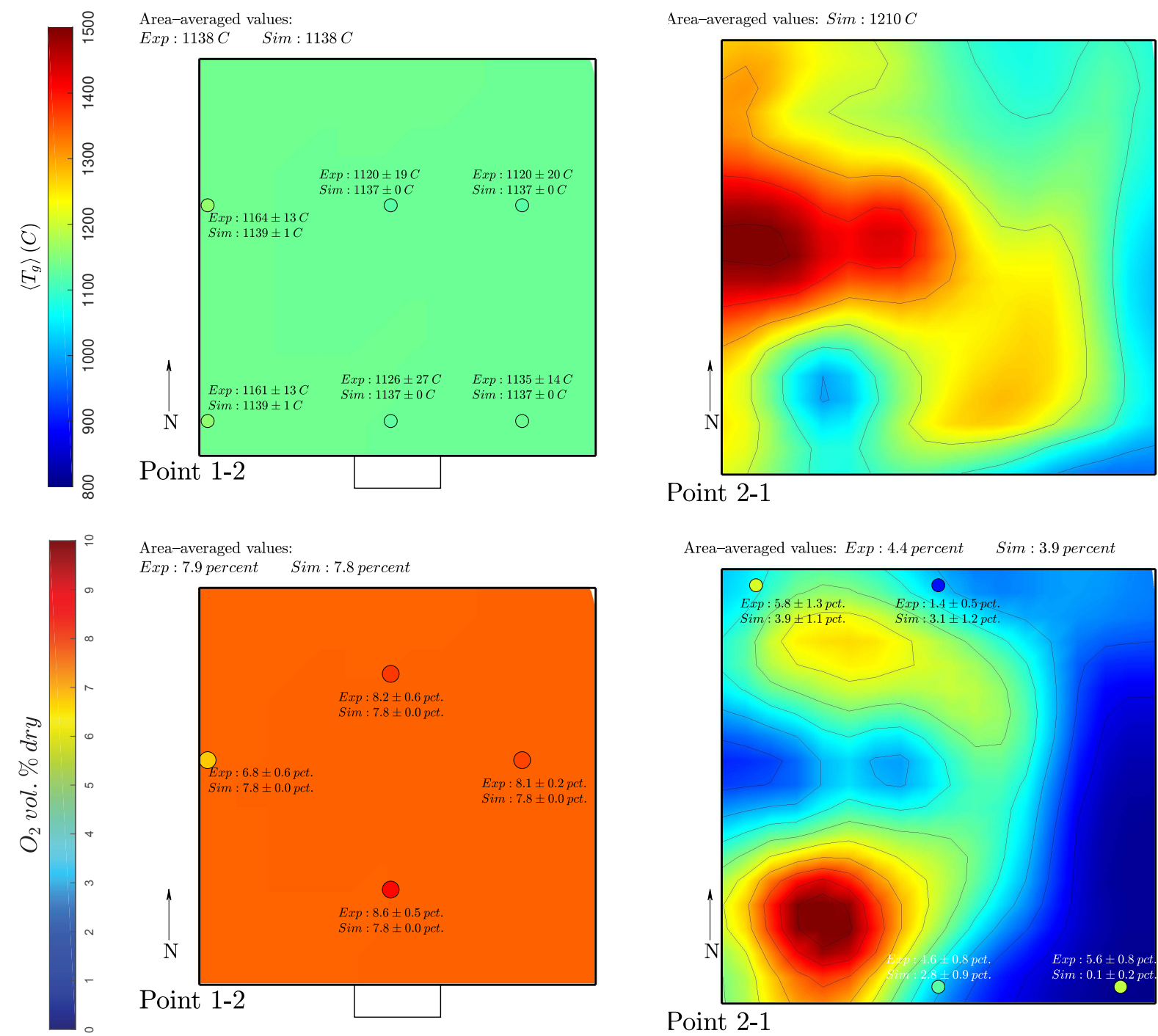

Area-averaged values:

Exp : 7.9 percent Sim $: 7.8$ percent

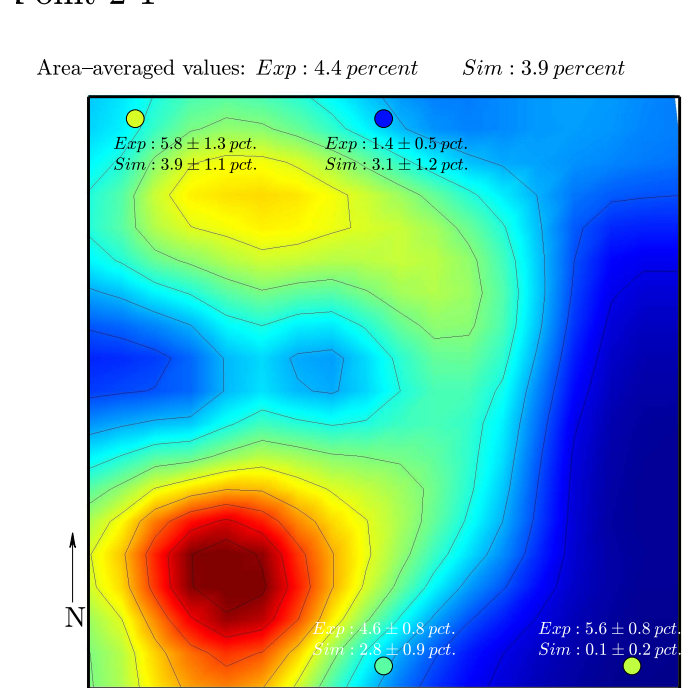

Point 1-2

Point 2-1

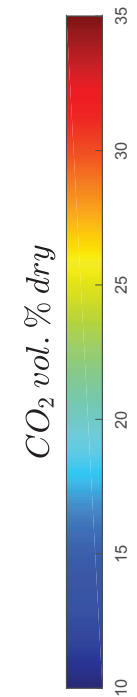

Area-averaged values:

Exp : 11.2 percent Sim : 11.8 percent
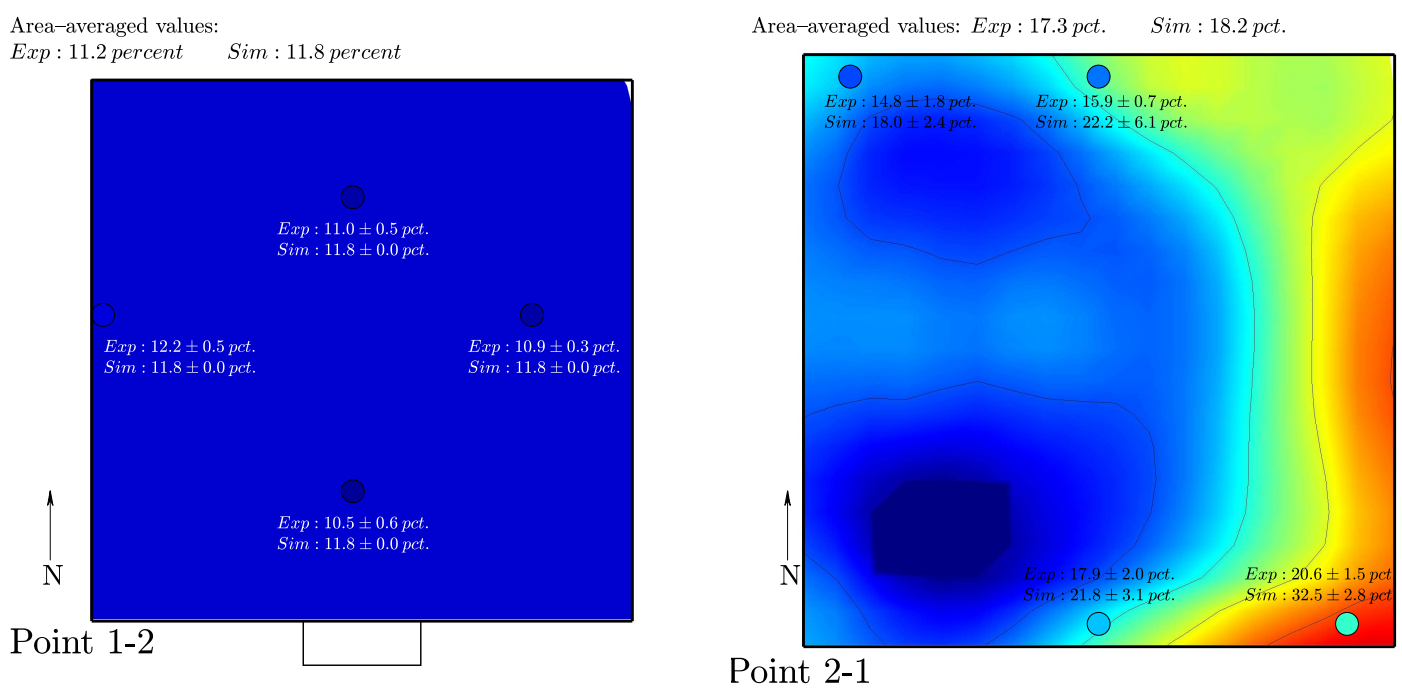

Point 2-1

Figure 5: Spacial distributions of gas temperature and species concentrations predicted from CPFD simulation and compared with the full-scale measurements at points 1-2 (left) and 2-1 (right). 

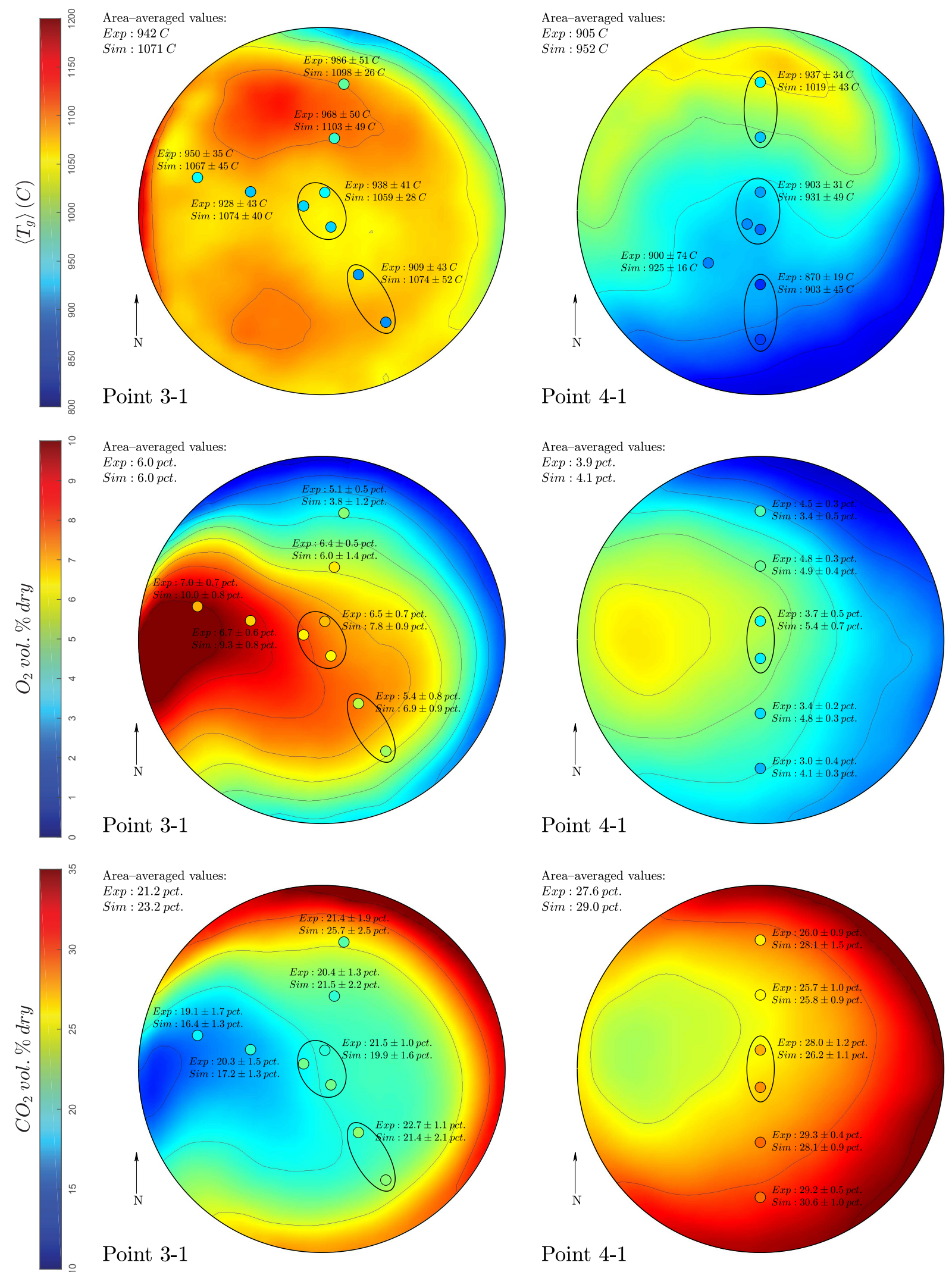

Figure 6: Spacial distributions of gas temperature and species concentrations predicted from CPFD simulation and compared with the full-scale measurements at points 3-1 (left) and 4-1 (right). 

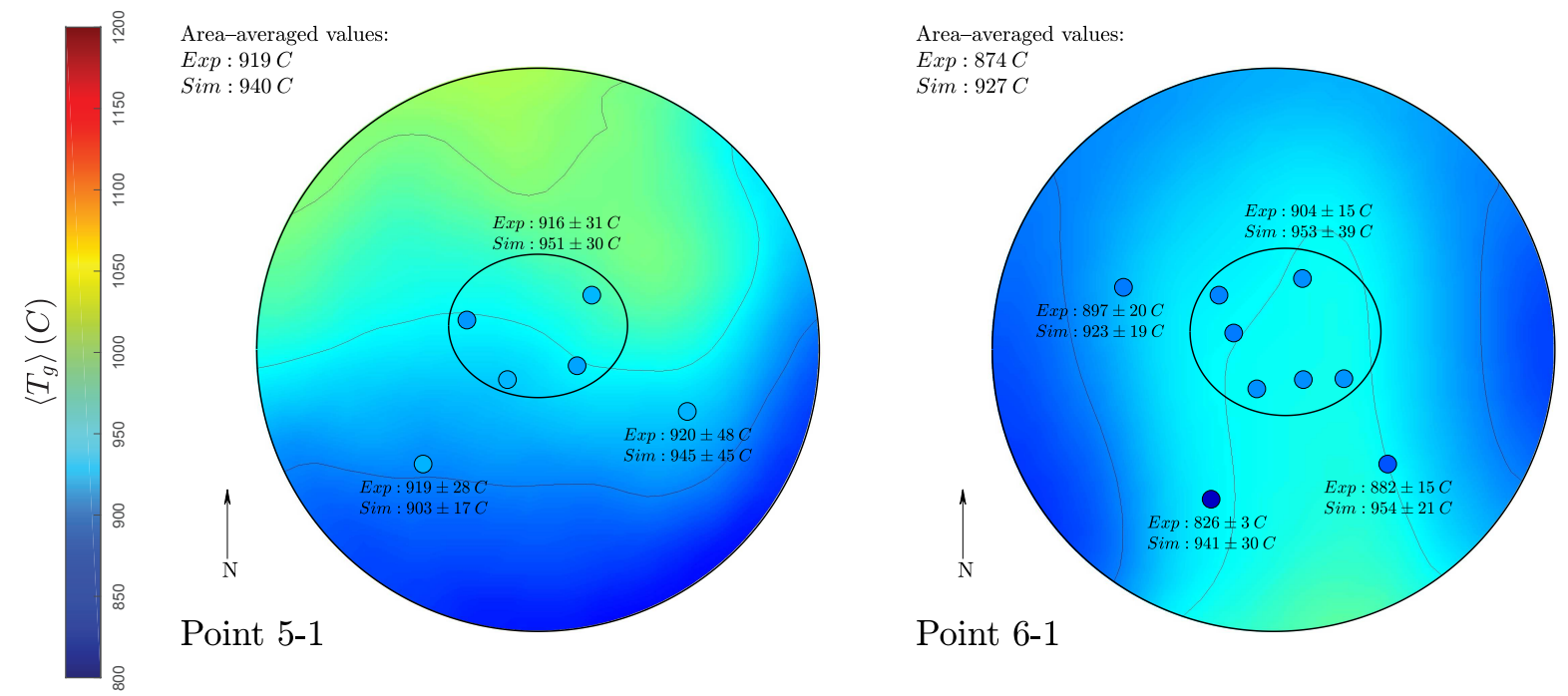

Figure 7: Spacial distributions of gas temperature predicted from CPFD simulation and compared with full-scale measurements at points $5-1$ (left) and 6-1 (right).

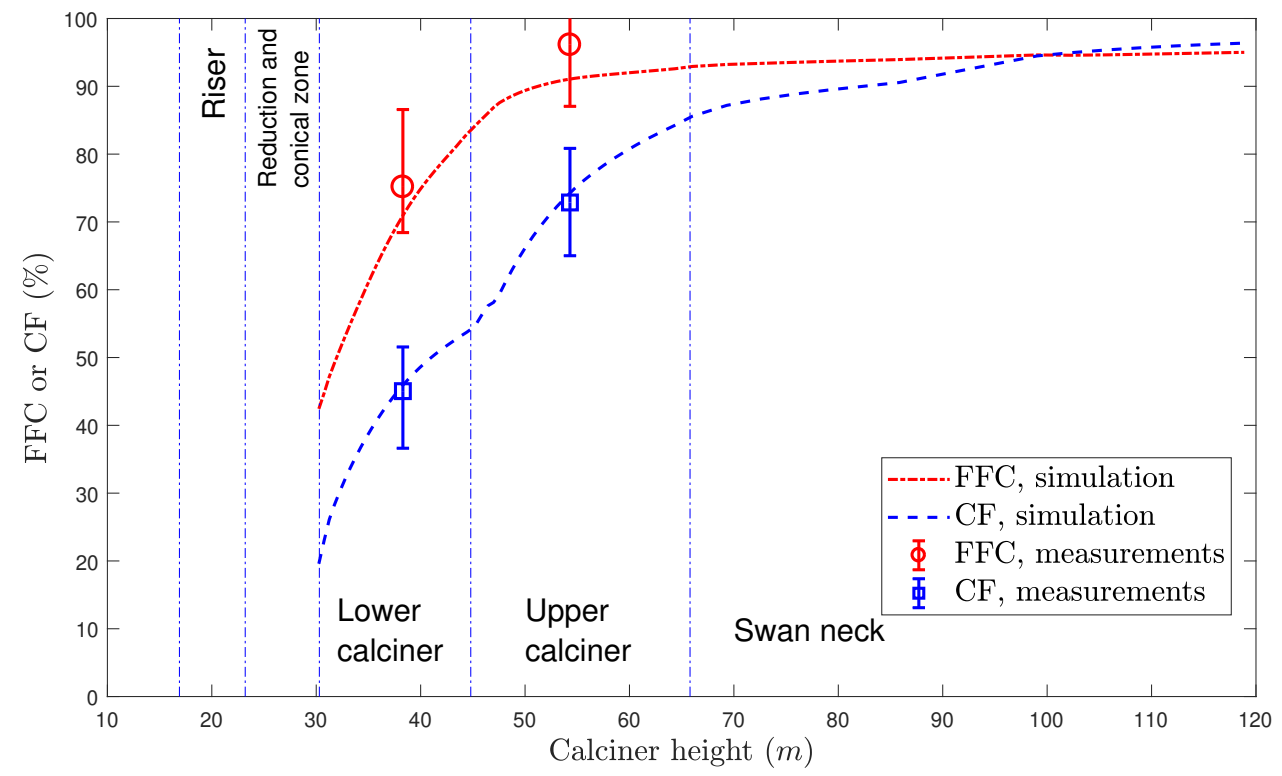

Figure 8: Fuel fraction converted $(F F C)$ and calcination factor $(C F)$ predicted from the CPFD simulation and compared with the estimated values from the measurements along the calciner. The symbols and errorbars represent arithmetic average and maximum/minimum (time-averaged) values of the point measurements in each cross-section. 

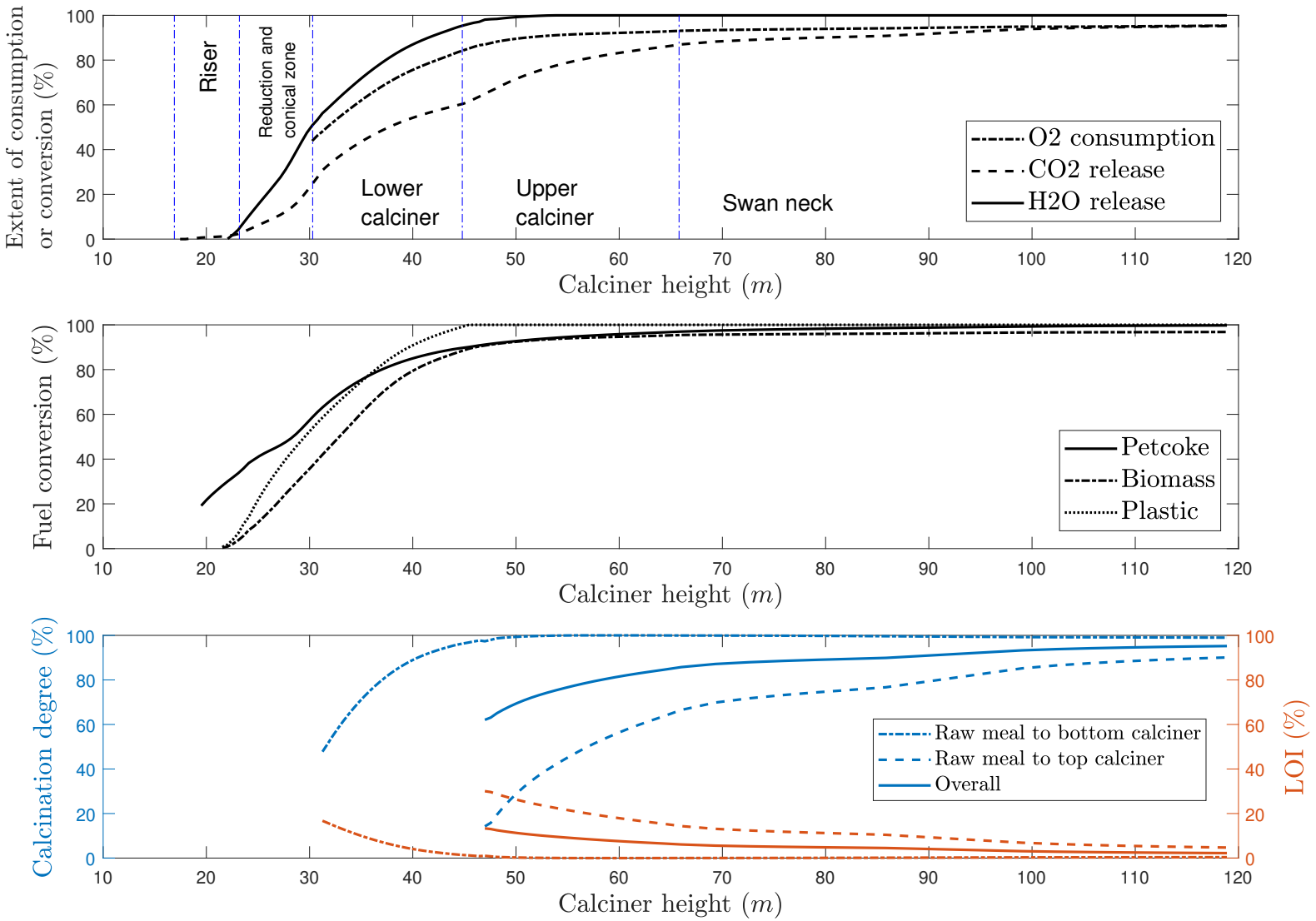

Figure 9: Predicted extents of $\mathrm{O}_{2}$ consumption and $\mathrm{CO}_{2}$ and $\mathrm{H}_{2} \mathrm{O}$ production (top), individual fuel conversion degrees based on the time-averaged mass flow rate of particles passing through different crosssections (middle), and the calcination degree and LOI of raw meal particles based on the time-averaged mass flow rates of particles passing through different cross-sections (bottom), along the calciner. 


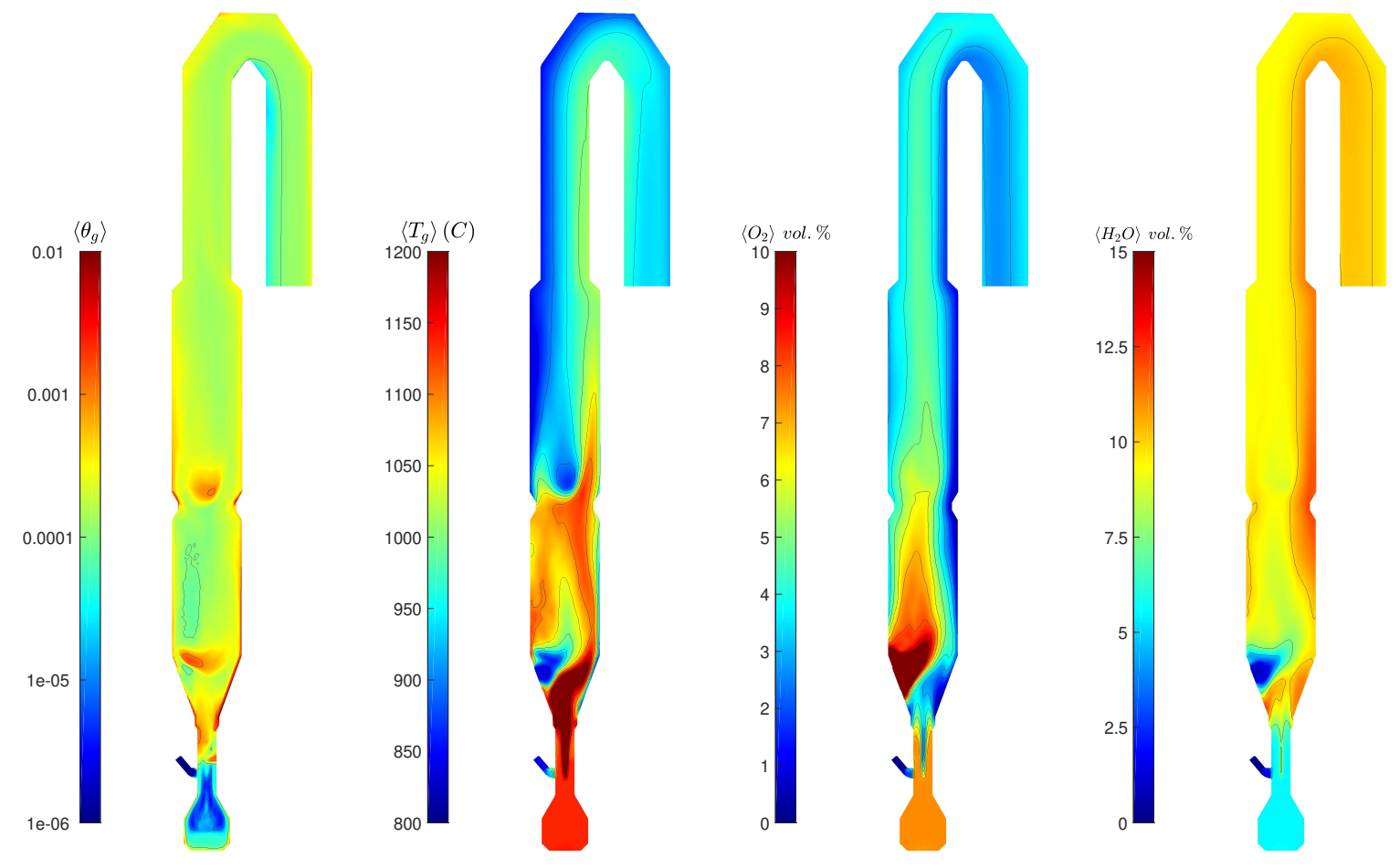

Figure 10: Predicted spacial distribution of time-averaged particle volume fraction, gas temperature, and gas $\mathrm{O}_{2}$ and $\mathrm{H}_{2} \mathrm{O}$ concentrations, respectively from left to right, along calciner height. 

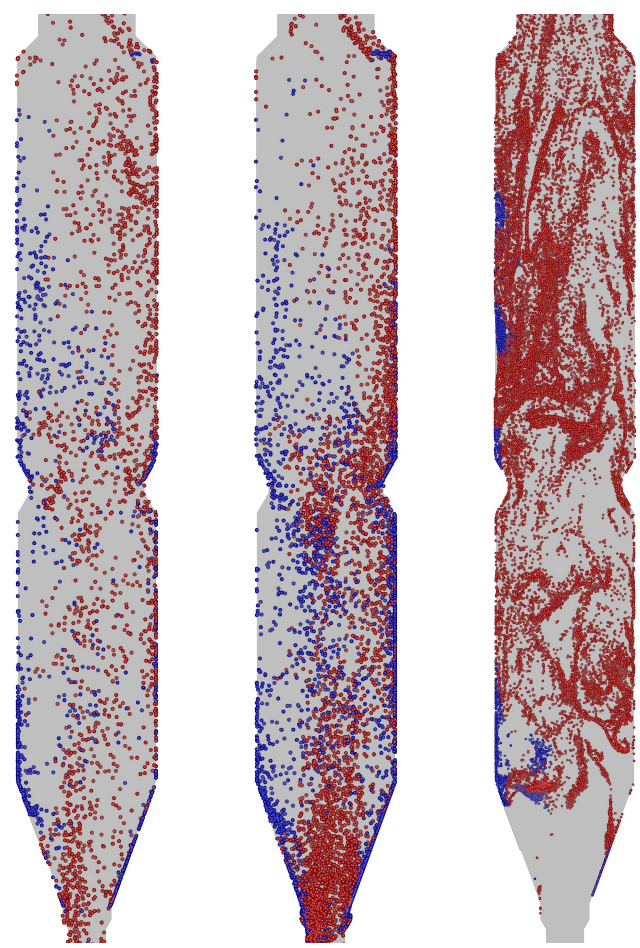

Figure 11: Example of an instantaneous distribution of biomass (left), plastic (middle), and raw meal (right) particle clouds from the CPFD simulation in a vertical slice of the calciner. The upward and downward moving particles are shown as red and blue colors, respectively. 